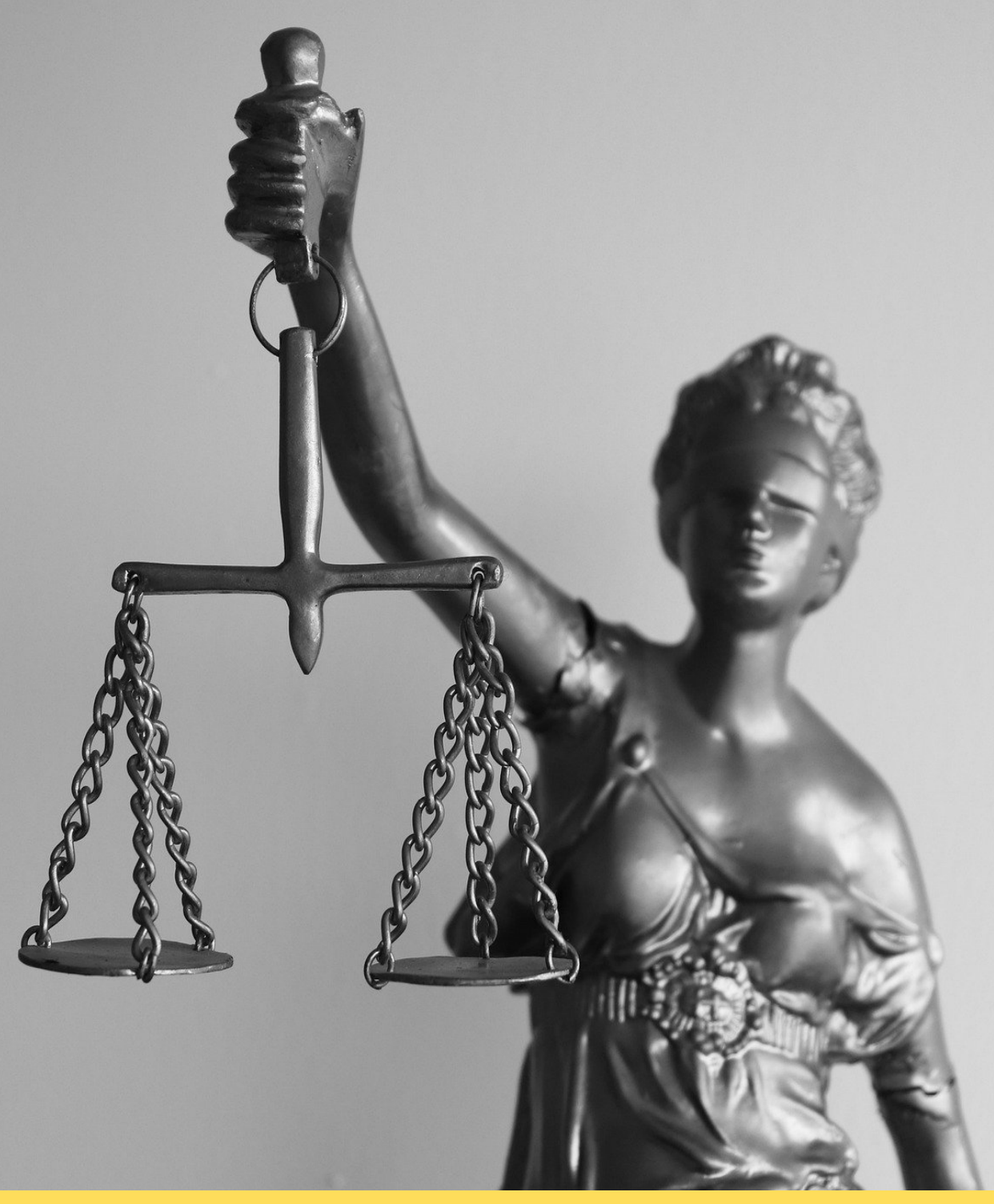

\title{
PESQUISA E ATUAÇÃO NO DIREITO
}

Lucas Melo Rodrigues de Sousa Thieser da Silva Farias

[Organizadores]

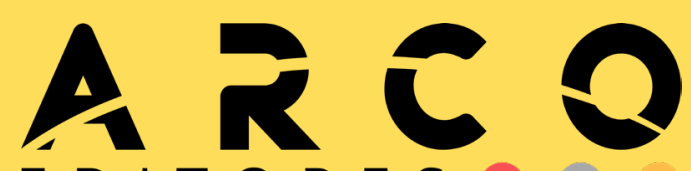

E D I TORES 


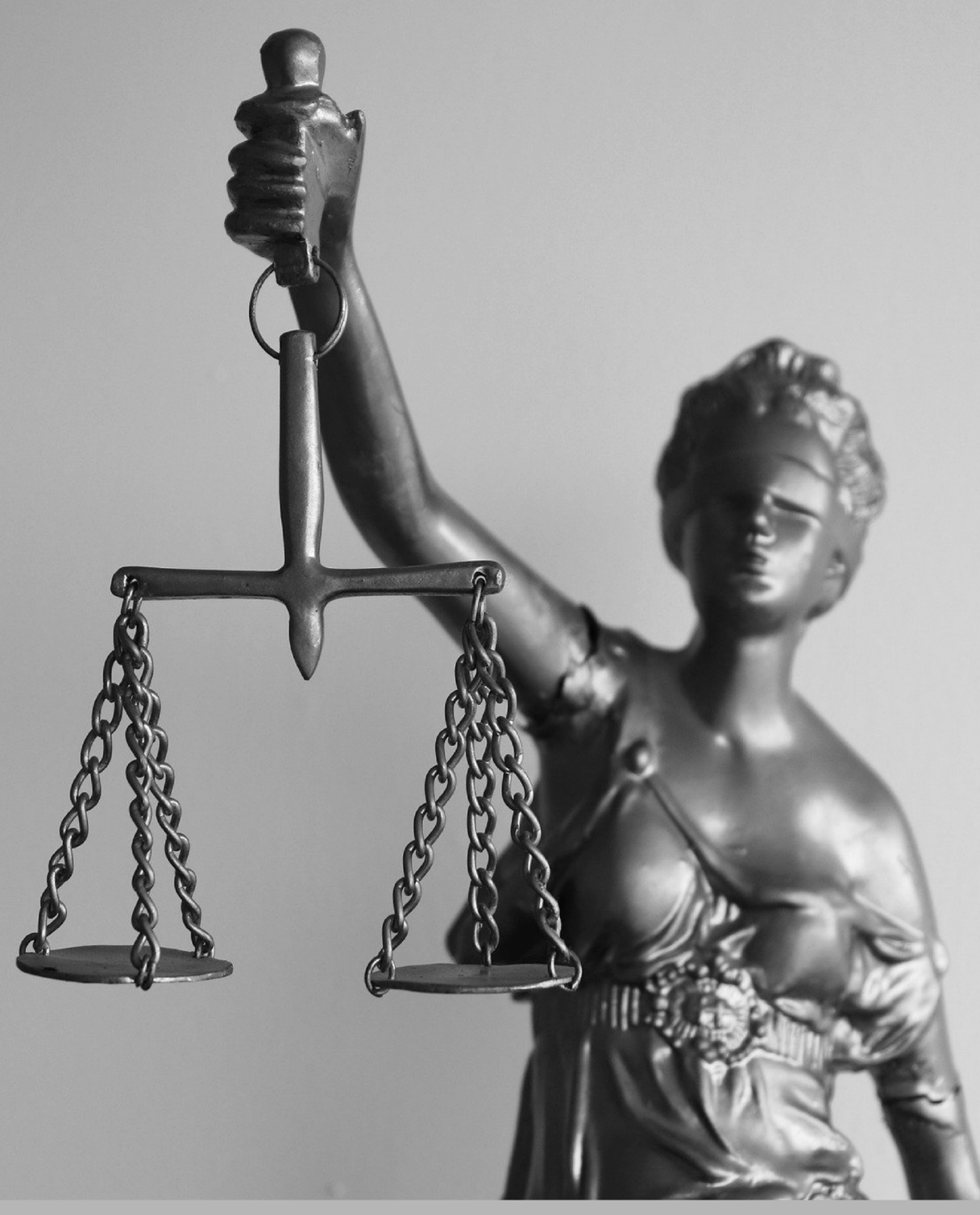

\section{PESQUISA E ATUAÇÃO NO DIREITO}

Lucas Melo Rodrigues de Sousa Thieser da Silva Farias

[Organizadores]

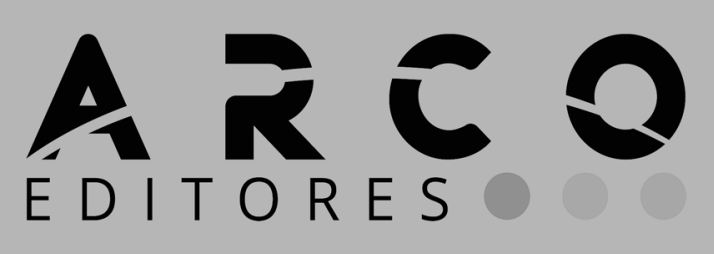




\section{CONSELHO EDITORIAL}

Prof. Dr. Adilson Tadeu Basquerote

Silva

UNIDAVI/SC

http://lattes.cnpq.br/8318350738705473

Profa. Msc. Jesica Wendy Beltrán

UFCE- Colômbia

http://lattes.cnpq.br/0048679279914457

Profa. Dra Fabiane dos Santos Ramos UFSM- Santa Maria/RS

http://lattes.cnpq.br/0003382878348789

Dr. João Riél Manuel Nunes Vieira de Oliveira Brito

UAL - Lisboa- Portugal.

http://lattes.cnpq.br/1347367542944960

Profa. Dra. Alessandra Regina Müller Germani

UFFS- Passo Fundo/RS

http://lattes.cnpq.br/7956662371295912

Prof. Dr. Everton Bandeira Martins

UFFS - Chapecó/SC

http://lattes.cnpq.br/9818548065077031

Prof. Dr. Erick Kader Callegaro Corrêa UFN- Santa Maria/RS

http://lattes.cnpq.br/2363988112549627

Prof. Dr. Pedro Henrique Witchs

UFES - Vitória/ES

http://lattes.cnpq.br/3913436849859138

Prof. Dr.Thiago Ribeiro Rafagnin

UFOB

http://lattes.cnpq.br/3377502960363268
Prof. Dr. Mateus Henrique Köhler

UFSM- Santa Maria/RS

http://lattes.cnpq.br/5754140057757003

Profa. Dra. Liziany Müller Medeiros

UFSM- Santa Maria/RS

http://lattes.cnpq.br/1486004582806497

Prof. Dr. Camilo Darsie de Souza

UNISC- Santa Cruz do Sul/RS

http://lattes.cnpq.br/4407126331414

Prof. Dr. Dioni Paulo Pastorio

UFRGS - Porto Alegre/RS

http://lattes.cnpq.br/7823646075456872

Prof. Dr. Leonardo Bigolin Jantsch

UFSM- Palmeira das Missões/RS

http://lattes.cnpq.br/0639803965762459

Prof. Dr. Leandro Antônio dos Santos

UFU- Uberlândia/MG

http://lattes.cnpq.br/4649031713685124

Dr. Rafael Nogueira Furtado

UFJF- Juiz de Fora/MG

http://lattes.cnpq.br/9761786872182217

Profa. Dra. Angelita Zimmermann

UFSM- Santa Maria/RS

http://lattes.cnpq.br/7548796037921237

Profa. Dra. Francielle Benini Agne

Tybusch

UFN - Santa Maria/RS

http://lattes.cnpq.br/4400702817251869

Copyright (c) Arco Editora, alguns direitos reservados.

Copyright do texto (c) 2022 os autores e as autoras.

Copyright da edição (c) 2022 Arco Editora. 
Diagramação e Projeto Gráfico : Gabriel Eldereti Machado

Imagen capa: www.pixabay.com

Revisão: dos/as autores/as.

Dados Internacionais de Catalogação na Publicação (CIP) (Câmara Brasileira do Livro, SP, Brasil)

Pesquisa e atuação no direito [livro eletrônico] / organização Lucas Melo Rodrigues de Sousa, Thieser da Silva Farias. -- Santa Maria, RS : Arco Editores, 2022.

$\mathrm{PDF}$

Vários autores.

ISBN 978-65-89949-60-2

1. Artigos - Coletâneas 2. Direito - Coletâneas

I. Sousa, Lucas Melo Rodrigues de. II. Farias, Thieser da Silva.

$22-97848$ CDU-34 (082)

Índices para catálogo sistemático:

1. Direito : Coletâneas 34(082)

Eliete Marques da Silva - Bibliotecária - CRB-8/9380

\section{dol $10.48209 / 978-65-89949-60-2$}

O padrão linguístico-gramatical, bem como o sistema de citações e referências bibliográficas são prerrogativas de cada autor. Da mesma maneira, o conteúdo e teor de cada capítulo é de inteira e exclusiva responsabilidade de seu respectivo autor. 
Não tenho tempo de desfraldar outra bandeira que não seja a da compreensão, do encontro e do entendimento entre as pessoas.

Elis Regina 


\section{APRESENTAÇÃO}

"Ubi societas, ibi jus". Diz o brocardo latino que, onde está a sociedade, estará o Direito. Enquanto Ciência Social Aplicada, interessa ao Direito (e a seus "operadores") os fenômenos sociais, políticos, culturais e econômicos que tenham a capacidade de influenciar as relações sociais.

Nesse sentido, a obra que se inicia consegue reunir cinco artigos destinados a pensar sobre variados ramos da Ciência Jurídica com reflexos diretos na coletividade. Mais do que isso: ao flertar com outras ciências, fomenta uma interdisciplinariedade capaz de ampliar a visão sobre temas polêmicas e/ou atuais que (re)clamam a atuação dos juristas à luz dos direitos humanos a fim de consagrar uma sociedade fraterna e pluralista, na esteira da orientação da Constituição de 1988.

Assim, esperamos que a leitura do livro seja profícua tanto para o aprimoramento pessoal quanto para orientar a rotina de pesquisadores e demais intérpretes do Direito, voltando um olhar à valorização da natureza, dos animais, da relação Estado-indivíduo e dos grupos humanos tradicionalmente excluídos.

Agradecemos a oportunidade concedida pela Editora Arco em conseguirmos congregar ensaios que transcendem a mera repetição dos ensinamentos dogmáticos e lançam mão de visão crítica para uma compreensão dos fatos sociais de acordo com as necessidades do século XXI. Em tempos desafiadores e de negacionismos de toda ordem, estudar é preciso, aprimorar-se é necessário e contribuir com o progresso geral é urgente.

Daí decorre o objetivo principal da coletânea: entender como a pesquisa e a atuação no Direito podem ser úteis na atualidade.

\section{Boa leitura!}




\section{SUMÁRIO}

\section{CAPÍTULO 1}

UM ESTUDO SOBRE A EXPERIMENTAÇÃO DE ANIMAIS SOB A ÓTICA DA CIÊNCIA BIOÉTICA .......................................................................

Nina Trícia Disconzi Rodrigues Pigatto

Thieser da Silva Farias

Arthur Posser Tonetto

doi: 10.48209/978-65-89949-60-1

\section{CAPÍTULO 2}

O DIREITO SISTÊMICO E A APLICAÇÃO DO MÉTODO DA CONSTELAÇÃO FAMILIAR NAS VARAS DE FAMÍLIA.......................................................24

Isabela Soares de Souza

Alexandre Jacob

doi: 10.48209/978-65-89949-60-0

\section{CAPÍTULO 3}

PARA ALÉM DA FAMÍLIA TRADICIONAL: ABERTURA DO CONCEITO E POLÍTICAS FAMILIARES NO DIREITO BRASILEIRO.

Lucas Melo Rodrigues de Sousa

doi: 10.48209/978-65-89949-60-3

\section{CAPÍTULO 4}

A SOCIEDADE DA DESINFORMAÇÃO.

Lucas Melo Rodrigues de Sousa

doi: 10.48209/978-65-89949-60-4 


\section{CAPÍtulO 5}

MEIO AMBIENTE ECOLOGICAMENTE EQUILIBRADO: DO DIREITO, DA MANUTENÇÃO E DAS TESES DOS TRIBUNAIS SUPERIORES..........77

Raphael Teixeira do Vale

Lucas Melo Rodrigues de Sousa

doi: 10.48209/978-65-89949-60-5

SOBRE OS ORGANIZADORES.

.91

SOBRE AS AUTORAS E OS AUTORES..............................................93 


\section{UM ESTUDO SOBRE A EXPERIMENTAÇÃO DE ANIMAIS SOB A ÓTICA DA CIÊNCIA BIOÉTICA}

Nina Trícia Disconzi Rodrigues Pigatto Thieser da Silva Farias Arthur Posser Tonetto 
"A compaixão para com os animais é das mais nobres virtudes da natureza humana." (Charles Darwin)

Resumo: O presente artigo tem por objetivo estudar brevemente a questão do uso de animais como cobaias em experimentos científicos. Munido da metodologia de pesquisa exploratória, o trabalho põe-se a refletir, num primeiro momento, acerca dos preceitos doutrinários acerca da experimentação animal. Na sequência, vale-se dos ditames normativos a fim de compreender como o ordenamento jurídico nacional procura estabelecer bases equilibradas e menos invasivas às práticas científicas com animais não-humanos.

Palavras-chave: Animais; Ciência; Cobaias; Experimentação.

Abstract: This article aims to briefly study the issue of using animals as guinea pigs in scientific experiments. Armed with exploratory research methodology, the work begins to reflect, at first, on the doctrinal precepts about animal experimentation. Next, it makes use of normative dictates in order to understand how the national legal system seeks to establish balanced and less invasive bases for scientific practices with non-human animals.

Keywords: Animals; Science; Guinea pigs; Experimentation.

\section{INTRODUÇÃO}

Diz o dito popular que a arte imita a vida (ou ao contrário). Nesse sentido, um dos filmes mais apropriados à discussão que se inicia é OKJA (2017), do cineasta coreano Bong Joon-Ho (responsável pelos aclamados O Hospedeiro e Expresso do Amanhã).

A despeito do emocionante enredo sobre a amizade entre a menina Mijha e a superporca Okja, o longa traz um importante pano de fundo científico-ético-social, ressaltando as ações desrespeitosas de criação e alimentação do referido suíno fêmea, uma vez que sua utilidade existe unicamente para "virar carne processada" em solo norte-americano. 
A "película" traz como pano de fundo as práticas condenáveis da indústria alimentícia sobre a experimentação de animais, uma rotina já comum voltada ao uso desses seres não-humanos como cobaias ou insumos para as refeições dos povos ou em testes para fármacos, vestuários e outros elementos cosméticos.

Diante disso, exsurge o seguinte questionamento: qual a intepretação do Direito quanto ao uso de animais em experimentos científicos? Para responder a tal indagação, o artigo se socorre de uma revisão de preceitos legais e doutrinários voltados à inquirição das pesquisas com animais não-humanos.

Nesse sentido, a primeira seção da pesquisa objetiva expor os entendimentos da literatura a respeito da utilização de animais não-humanos em experiências científicas. A posteriori, apresenta as legislações cujo teor intentam garantir a dignidade desses seres por meio da mitigação de seu sofrimento em testes e verificações empíricas das ciências.

\section{OS ANIMAIS COMO COBAIAS EM EXPERIMENTOS CIENTÍficos}

Nos últimos vinte anos, cresceu consideravelmente no Brasil o interesse pelo estudo da "Questão Animal" devido à proliferação de disciplinas de graduação (ATAÍDE JÚNIOR, 2018), monografias de conclusão de curso, dissertações e teses inclinadas à pesquisa destes "novos direitos" componentes, na crença de Nunes Júnior (2019), da Quinta Dimensão de direitos fundamentais.

Uma das múltiplas discussões empreendidas na Academia acerca da temática em epígrafe orbita em torno da experimentação animal, assunto que evoca um interesse transdisciplinar, a citar a Biologia, Zootecnia, Medicina Veterinária, Farmácia, Bioética (DIAS, 2018; DISCONZI, 2020) e Antropologia. No campo das ciências sociais aplicadas, exsurgem os debates em ramos do Direito, a exemplo do Direito Constitucional, dos Animais, Ambiental, Civil e Penal.

Levai (2008, p. 1) conceitua experimentação animal como "toda e qualquer prática que utiliza animais para fins didáticos e científicos". Paixão (2001) e Greif 
(2003) pontuam que os experimentos podem se encaixar, basicamente, em dois tipos: a) dissecação, "que consiste na separação, por meio de instrumentos cirúrgicos, de partes do corpo ou órgãos de animais mortos", e b) vivissecção, "que é a intervenção em animais vivos ou recém-abatidos” (DISCONZI, 2020, p. 149).

Os dicionários costumam definir cobaias como "qualquer pessoa ou animal utilizado(a) em experimentos científicos". Normalmente, cientistas e pesquisadores preferem usar os animais em seus testes para averiguar hipóteses, verificar dados e obter resultados para os procedimentos empreendidos.

A Ciência (latu sensu) busca se aprimorar com o decorrer do tempo, tentando dar respostas aos anseios da humanidade, seja para cura de doenças, seja para invenção de procedimentos que visem à melhoria da qualidade de vida da população. É ínsito à essência do "fazer" científico a aspiração pelo progresso.

Daí advém a necessidade das cobaias, pois que são instrumentos de experimentação e testes visando ao aperfeiçoamento das técnicas em desenvolvimento. Assim, a ciência utiliza, nesse intento, animais, elementos da natureza e até mesmo os seres humanos. Porém, nem sempre esse uso aconteceu de maneira ponderada, equilibrada ou sensata, ante o emprego de métodos cruéis ou ultrajantes.

Nesse sentido, Santos e Gois (2007) apontam exemplos históricos de abusos praticados por cientistas e pesquisados ao longo da Civilização. Segundo os autores, nas Idades Média e Moderna criminosos eram usados em investigações e "pesquisas" sobre anatomia e fisiologia; já no século $X X$, o regime nazista valeu-se de algumas minorias (judeus, ciganos, homossexuais, mulheres, pessoas com deficiência e etc.) como alvos preferenciais (ou "bodes expiatórios") para testagem de produtos farmacológicos ou expostos à atuação de agentes químicos, dentre outras formas desumanas de experimentações, com escopo de aplicar as descobertas ao desenvolvimento da "raça ariana".

A morte dessas cobaias humanas estarreceu a comunidade norte-americana e parece ir ao encontro ao pensamento de Michel Foucault quando aduz 
sobre uma lógica de "controle" ou descarte de corpos inservíveis (FOUCAULT, 1987), principalmente no que concerne a pobres, negros, portadores de doenças incuráveis (AIDS, por exemplo) ou pessoas com necessidades especiais, tidos como substituíveis e desnecessários à sociedade.

\section{A bioética como norte para a experimentação animal}

Diante de tantos horrores praticados em nome do progresso científico, exsurgiu o Relatório Belmont nos Estados Unidos em 1971, impulso decisivo para a conformação da ciência Bioética, apregoando, na visão de Amaral e Pona (2014) e Pessanha (2014), um plexo de princípios reitores a orientarem as pesquisas médicas, científicas ou ambulatoriais, de modo a conduzir as posturas de profissionais, pacientes e do Estado.

Sucintamente, são eles: a) Respeito à individualidade (ou "autonomia", PESSANHA, 2014): o experimento precisa ser depurado/livre de coerções externas. Em suma, tendo em vista o primado do bem-estar animal, a pesquisa médico-científica só pode ser realizada se acompanhada por profissionais habilitados e sob a supervisão de um comitê de ética, prevenindo abusos e mais tratos; b) Beneficência (ligado ao juramento de Hipócrates, ou seja, proporcionar o máximo de bem-estar com o mínimo de danos aos homens e mulheres), e c) Justiça, por meio do balanceamento entre as aspirações particulares do paciente e os interesses da coletividade, com distribuição equânime de recursos bioquímicos.

Os postulados se estendem, por óbvio, aos animais, pois eles, enquanto partícipes dos ecossistemas do globo terrestre, são portadores de direitos subjetivos, notáveis "partes do todo" concebido pela "Mãe Gaia" (SHIVA, 2013).

Nessa toada, interessante é a definição trazida por Séguin (2005):

A bioética tem como objeto garantir que sejam efetuadas, dentro de padrões éticos e de respeito à dignidade humana, todas as intervenções médicas, desde as exercidas no processo inicial da vida, como a fecundação in vitro, até as que culminam com a extinção da pessoa. A bioética procura respostas morais e interrogações técnicas da medicina e da biologia, com um cunho educativo, de garantia ao acesso à informação e à sensibilização do público em geral para essas questões. Caberá ao Bio- 
direito impor condutas e sanções pelo seu descumprimento (SÉGUIN, 2005, p. 44).

Por mais simples que possa parecer (ante a necessidade dos experimentos), boa parte da comunidade científica, da sociedade civil e de ativistas da causa animal sempre observaram práticas experimentais com (justificadas) ressalvas, haja vista que nem sempre os animais são submetidos a procedimentos equilibrados ou indolores.

Os argumentos de críticas são de diversos matizes, destacando-se a questão de dominância dos homens sobre os animais e o sofrimento causado nestes em pesquisas laboratoriais. O contexto exige destacar a milenar relação entre seres humanos e animais na história do planeta. Segundo Costa e Reis (2014),

a relação dos homens com eles é bem mais antiga. A domesticação de alguns animais ocorreu junto com os primeiros processos civilizatórios. De certa forma, os animais sempre foram utilizados de acordo com as conveniências, isto é, em rituais de sacrifícios, no auxílio a determinados trabalhos e para alimentação (COSTA; REIS, 2014, p. 2).

Com o decorrer do processo civilizatório, a incipiente relação humano-animal aumentou por diversos fatores: convívio doméstico, utilização em caças, trabalhos agrícolas e abastecimento das demandas por fontes de comidas, situação em que bois, vacas, frangos e porcos passaram a ter função alimentícia para determinadas comunidades.

O crescimento das massas populacionais (mormente nas áreas urbanas)

exigiu um aumento da criação de animais que, muitas vezes, passaram a viver e serem criados em condições extremamente precárias. Os animais deviam suprir a alta demanda. Neste processo, a preocupação está no resultado da produção, mas não no procedimento (o tratamento dado aos animais) (COSTA; REIS, 2014, p. 3).

Doravante, criou-se uma cultura de superioridade e prevalência dos indivíduos sobre os "animais irracionais", como se esses existissem tão somente para servirem aos interesses daqueles. 
Munidos de tal lógica (ilógica?), muitas pessoas arrogaram para si a prerrogativa de determinarem, inclusive, a decisão sobre a vida e a morte dos animais, postura que motivou toda sorte de maus tratos, descaso e agressões a esses seres, seja no convívio doméstico, seja em estudos químico-farmacológicos.

Embora os animais sempre tenham sido usados conforme o livre-arbítrio dos seres humanos para a consecução dos mais diversos objetivos, Paixão (2011) e Orlans (1993) contam que a utilização de animais em experimentos científicos banalizou-se como técnica das ciências ao longo do século XIX. Muitos "bichos" eram mantidos com o desiderato exclusivo de servirem às experimentações, sendo sacrificados ao fim da verificação empírica. De acordo com Paixão (2001),

A experimentação animal apresentava-se como um fenômeno crescente até atingir seu pico em 1976, e a partir de então teve início um declínio. [...] esse crescimento deveu-se aos benefícios advindos da utilização de animais e, consequentemente, à sua adoção pelas indústrias. Um grande crescimento, especialmente da indústria farmacêutica, ocorreu nessa época, assim como a expansão da aplicação dos chamados testes de segurança, tal como o teste de DL50 (que surgiu em 1927) e o teste Draize (surgido em 1944) (PAIXÃO, 2001, p. 13).

De outra banda, como se não bastasse o uso irresponsável de animais na testagem de vacinas, procedimentos cirúrgicos ou confecção de vestimentas, são diversos os casos conhecidos de utilização de animais para a produção de cosméticos ou fins eminentemente mercantis, com a criação de espécies que garantam lucros a grandes corporações do ramo alimentício. Levai (2008) apud Disconzi (2020) pondera que

no Brasil, a exemplo do que ocorre em quase todo o mundo, diariamente, milhares de animais perdem a vida em experimentos cruéis, submetidos a testes cirúrgicos, toxicológicos, comportamentais, neurológicos, oculares e cutâneos, entre outros, sem que haja limites éticos ou mesmo relevância científica em tais atividades. [...] Com efeito, ratos, coelhos, gatos, cães, rãs, macacos, porcos, cavalos, dentre outros animais, tornam-se cobaias nas mãos de pesquisadores, tanto de indústrias (cosméticas e farmacêuticas), quanto de centros de pesquisas e de faculdades das áreas biomédicas (LEVAI (2008) apud Disconzi (2020, p. 162). 
Costa e Reis (2014) complementam:

A área de cosméticos também contribuiu para os maus tratos com os animais. Ao longo do século XX, principalmente na sua segunda metade, os animais passaram a ser utilizados em experimentos para a fabricação de produtos de beleza. Os experimentos científicos em suas mais diversas áreas foram responsáveis por inúmeros casos de violência e sadismo com animais. Em prol de projetos e descobertas científicas, sem uma legislação própria regulatória, a utilização indiscriminada proporcionou os relatos mais cruéis da relação humanos/animais (COSTA; REIS, 2014, p. 3. Grifos).

No que toca ao uso de animas em experimentação em pesquisas relacionadas à indústria de cosméticos, alguns estados da Federação, tais quais o Rio de Janeiro (Lei $n^{\circ} 7.814 / 2017$ ) e o Amazonas (Lei $n^{\circ}$ 289/2015), vêm avançando em termos de produção legislativa que vise coibir a utilização de animais não-humanos para os referidos fins.

A título de curiosidade, recorda-se que instituições como a Associação Brasileira da Indústria de Cosméticos, Higiene Pessoal e Perfumaria (ABIHPEC) têm utilizado o argumento de que a Lei AROUCA (Lei no 11.974), ao permitir a utilização de animais para experimentos e não proibir de maneira taxativa sua utilização em testes com cosméticos, pacifica a questão e, à medida em que os estados editam normas proibitivas a tais testagens, extrapolariam a competência legislativa por irem de encontro à lei federal (BRASIL, 2008).

Instado a se manifestar por meio das Ações Direita de Inconstitucionalidade de números 5995 e 5996, o Supremo Tribunal Federal firmou o entendimento de que os estados-membros possuem competência para alargar a proteção conferida aos animais não-humanos para além daquela plasmada pela lei federal, caso a medida objetive a mitigação de práticas cruéis e desnecessárias à ciência.

Não obstante, entendeu o Pretório Excelso como de competência privativa da União legislar sobre a circulação e comercialização de produtos cosméticos, de higiene e de perfumaria que utilizem de animais em seu processo de produção e testagem. Pois que, até o momento, a legislação federal é silente sobre tal 
matéria, seguem sendo amplamente comercializados os mencionados produtos, inclusive nos estados-membros que não permitem o uso de animais em sua testagem (BRASIL, 2018).

\section{A busca da legislação por mitigar práticas INVASIVAS NAS EXPERIÊNCIAS COM ANIMAIS}

Não há certeza sobre o momento histórico de advento das primeiras convicções em favor dos direitos dos animais. Greif (2003) e Paixão (2001) indicam que, em meados do século XVIII, o filósofo iluminista Voltaire e o jurista britânico Jeremy Bentham já debatiam acerca da questão em exame, refletindo sobre uma eventual contradição da natureza acaso houvesse superioridade de homens e mulheres em relação aos animais não-humanos.

Paixão (2011, p. 55) indica: "Mais tarde, ainda seriam as ideias de Bentham a impulsionar o movimento de liberação animal, como [...] no debate que se dá a partir da década de 70".

Destarte, a partir da segunda metade do século XX, surgiram pensadores, ativistas e filósofos da causa animal inclinados aos estudos que visavam à eliminação da experimentação e de outras práticas nocivas à integridade dos animais. Com efeito, destaque-se Tom Regan, Peter Singer e Richard Ryder.

Este último cunhou a expressão "especismo", presente na paradigmática obra sobre os direitos dos animais denominada Animals, Men, and Morals: An Enquiry into the Maltreatment of Non-Humans de 1972 (COSTA; REIS, 2014). No manuscrito, Ryder apregoa:

[...] assim como os dois "racismo" e "especismo" são termos vagos e usados para classificação de criaturas vivas, em grande parte, tendo em vista sua aparência física, e também qualquer outra analogia que possa ser feita entre eles. A discriminação, tendo como fundamentação, a raça, embora considerado moralmente errada dois séculos atrás, hoje em dia é largamente condenada. Similarmente, como ocorreu com o racismo, as

1 Singer (2010, p. 11) atribui um conceito mais profundo à teoria de Ryder, definindo-o como o "preconceito ou atitude tendenciosa de alguém a favor dos interesses de membros da própria espécie, contra os de outras". 
mentes iluminadas também verão com extrema aversão o "especismo". As duas formas, ilógicas, de preconceito são iguais. Se é aceito como moralmente errado infligir, deliberadamente, sofrimento em uma criatura humana também é logico considerar errado infligir sofrimento em qualquer individuo inocente ou a qualquer espécie (RYDER, 1972, p. 81).

Em respeito à dignidade animal (COSTA; REIS, 2014), Singer (2010) vai além ao propor uma redução drástica ou até mesmo a total eliminação do uso de carne animal na dieta humana como forma de barrar o vigoroso abate de suínos, bovinos e de outras espécies habitualmente à disposição para satisfazer o paladar de homens e mulheres em todo o globo.

Rech (2013) elucida que os laboratórios valem-se de inúmeros membros do Reino Animalia (ou Metazoa) para a consecução de procedimentos. A título de curiosidade, citam-se: ratos (utilizados para investigação do sistema imunológico), coelhos (submetidos a testes oculares), gatos (experiências cerebrais), cães (treinamento de cirurgias), rãs (observação didática sobre reações a estímulos musculares), macacos (análises comportamentais), porcos (estudos sobre cicatrização), cavalos (investigação a respeito de sorologias), peixes e pombos (estudos toxicológicos), dentre outros.

Diante desse quadro, organismos internacionais, grupos ligados à ciência e ONG's passaram a defender o uso respeitoso e ponderado dos animais em experimentos científicos, incentivando o surgimento das primeiras normativas destinadas à valorização e proteção dos animais. Lastreada no preceito doutrinário da dignidade animal (analogia ao princípio geral da dignidade humana), tem-se a Declaração Universal de Direitos dos Animais proclamada pela UNESCO em 1978 (COSTA; REIS, 2011):

\section{DECLARAÇÃO UNIVERSAL DOS DIREITOS DOS ANIMAIS}

Art. $1^{\circ}$ ) Todos os animais nascem iguais perante a vida e têm os mesmos direitos à existência;

Art. $\left.2^{\circ}\right) \mathrm{O}$ homem, como a espécie animal, não pode exterminar outros animais ou explorá-los violando este direito; tem obrigação de colocar os seus conhecimentos a serviço dos animais; 
Art. $3^{\circ}$ ) 1) Todo animal tem direito a atenção, aos cuidados e a proteção dos homens;

2) Se a morte de um animal for necessária, deve ser instantânea, indolor e não geradora de angústia;

Art. $4^{\circ}$ ) 1) Todo animal pertencente a uma espécie selvagem tem direito a viver livre em seu próprio ambiente natural, terrestre, aéreo ou aquático, e tem direito a reproduzir-se;

2) Toda privação de liberdade, mesmo se tiver fins educativos, é contrária a este direito;

Art. $5^{\circ}$ ) 1) Todo animal pertencente a uma espécie ambientada tradicionalmente na vizinhança do homem tem direito a viver e crescer no ritmo e nas condições de vida e liberdade que forem próprias da sua espécie [...] (BÉLGICA, 1978)

Ademais, gize-se a existência da Declaração do Meio Ambiente da Conferência das Nações Unidas em Estocolmo (1992) e, no caso nacional, a Constituição Federal de 1988. A atual Constituição Cidadã preconiza:

Art. 225. Todos têm direito ao meio ambiente ecologicamente equilibrado, bem de uso comum do povo e essencial à sadia qualidade de vida, impondo-se ao Poder Público e à coletividade o dever de defendê-lo e preservá-lo para as presentes e futuras gerações.

$\S 1^{\circ}$ Para assegurar a efetividade desse direito, incumbe ao Poder Público:

I - preservar e restaurar os processos ecológicos essenciais e prover o manejo ecológico das espécies e ecossistemas;

$[\ldots]$

VII - proteger a fauna e a flora, vedadas, na forma da lei, as práticas que coloquem em risco sua função ecológica, provoquem a extinção de espécies ou submetam os animais a crueldade (BRASIL, 1988).

Ataíde Junior (2018) e Disconzi (2020) apontam que a Carta Magna de 1988 ocupa posição de destaque na história constitucional brasileira ao vedar enfaticamente a crueldade para com animais, consoante preleciona o seu artigo 225, parágrafo $1^{\circ}$, inciso VII, in fine. No sentir da professora, "essa garantia constitucional torna a proteção animal fundamento básico de nossa sociedade e estende, a esses indivíduos, o conceito de dignidade" (DISCONZI, 2020, p. 164). 
Neste diapasão, Eberle (2006) ensina que, por força do comando inserto no dispositivo constitucional em epígrafe, os animais devem ser vistos enquanto sujeitos de direitos imbuídos de dignidade, e suscetíveis, portanto, à pronta tutela jurisdicional em caso de vilipêndio à sua existência.

Em sua tese de doutorado, a autora reuniu uma vasta gama de entendimentos filosóficos e jurídicos para comprovar que já não existem mais motivos para se colocarem em lados opostos cidadãos e animais não-humanos (COSTA; REIS, 2014, p. 13). Propugna que as relações entre tais espécies sejam vistas mediante um novo ângulo", ou seja, "com sensibilidade/solidariedade que todos os animais merecem do homem" (EBERLE, 2006, p. 335).

Tais iniciativas demonstram a possibilidade de que a ciência continue a avançar mesmo que se torne reflexiva quanto à real necessidade da experimentação animal. Por mais que possa ser ousado e, nos limites atuais, irreal propor o abandono total do uso de animais com objetivos científicos, é bem verdade dizer que já é possível a utilização de métodos alternativos de pesquisa que não demandem o uso de animais não humanos.

Relevante esclarecer quais são as estratégias aceitas pelas doutrinas animalista e biomédica com o condão de abrandar as práticas incisivas na integridade dos seres não-humanos (GREIF, 2003): a diminuição da incidência do uso de animais, a substituição e a redução da quantidade de animais utilizados - são os métodos conhecidos como $3 \mathrm{R}$, em inglês: replacement (substituição), reduction (redução) e refinement (refinamento) da incidência.

Dias (2021) aponta para uma série de métodos alcançáveis ao pesquisador, tais como a utilização de emuladores, cadáveres, pesquisa com células e diversas outras alternativas que podem, perfeitamente, alcançar maior proteção e dignidade ao animal não-humano. 


\section{CONSIDERAÇÕES FINAIS}

Diante da constatação de que os animais não-humanos são seres dotados de senciência, não há mais fundamento em continuar sustentando que o sofrimento causado por indivíduos a outros seres possa ser ignorada e entendida como mero efeito colateral do progresso. Assim, há que se pensar métodos alternativos à utilização de animais em experimentações, sejam elas essencialmente científicas e acadêmicas, sejam elas atreladas à obtenção de capital.

Para tanto, ainda que o abandono da experimentação animal transcenda a mera edição de leis mais severas e protetivas, é necessário refletir sobre as medidas a serem tomadas para que o uso desmedido e cruel de animais em experimentos venha a ser paulatinamente suplantado.

Destarte, vê-se necessário conceber os animais não-humanos como sujeitos de direitos e merecedores de um arcabouço normativo que lhes proteja a vida e a dignidade. Afora isso, já passou da hora de se levarem a sério os mecanismos alternativos de pesquisa, com uma fiscalização ativa pelo Poder Público e pela sociedade civil de modo geral, no fito de frear o uso irresponsável e clandestino de animais em vivissecção e em outras práticas dolorosas.

\section{REFERÊNCIAS}

AMARAL, Ana Claudia Corrêa Zuin Mattos de; PONA, Éverton Willian. Globalização Bioética: a universalidade do paradigma fundado na dignidade humana. In: CONGRESSO NACIONAL DE PESQUISADORES EM DIREITO, 3., 2014, Curitiba. Anais... Curitiba: CONPEDI, 2014, p. 525- 553.

ATAÍDE JUNIOR, Vicente de Paula. Introdução ao Direito Animal. Revista Brasileira de Direito Animal, Salvador, v. 13, n. 3, p. 48-76, Set-Dez. 2018.

BRASIL. Constituição da República Federativa do Brasil. Brasília: Senado Federal, 1988. Disponível em: http://www.planalto.gov.br/ccivil_03/constituicao/ constituicao.htm. Acesso em: 11 mai. 2021.

BRASIL. Lei 11.794/2008. In: Vade Mecum. 
COSTA, Beatriz Souza; REIS, Émilien Vilas Boas. Animais: Sem deixar a sombra dos homens para a garantia dos seus direitos. In: CONGRESSO NACIONAL DE PESQUISADORES EM DIREITO, 2, 2014, Curitiba. Anais... Curitiba: CONPEDI, 2014, p. 525- 553.

DIAS, Edna Cardozo. A Tutela Jurídica dos Animais. Belo Horizonte: Edna Cardozo, 2018. (Formato e-book).

DIAS, Edna Cardozo. Pandemia e o florescer de uma nova civilização.

DISCONZI, Nina Trícia. Por que os animais são como nós: o uso/abuso dos animais nas práticas didáticas. In: Laura Cecília Fagundes dos Santos Braz. Elas escrevem Edna: homenagem à pioneira do Direito Animal no Brasil, 2020. (Formato e-book).

EBERLE, Simone. Deixando a Sombra dos Homens: Uma Nova Luz sobre o Estatuto Jurídico dos Animais. 2006. 431 f. Tese de Doutorado (Direito Civil) Faculdade de Direito da Universidade Federal de Minas Gerais. Belo Horizonte, $417 \mathrm{p}$.

FOUCAULT, Michel. Vigiar e Punir: Nascimento da Prisão. Trad. Raquel RamaIhete. Petrópolis: Vozes, 2007.

GREIF, Sérgio. Alternativas ao uso de animais vivos na educação pela ciência responsável. São Paulo: Instituto Nina Rosa, 2003.

JOON-HO, Bong. Okja. Elenco: Tilda Swinton, Paulo Dano, Ahn Seo-hyun, Jake Gyllenhaal. - EUA/COR - 2017 - 120 min.

LEVAI, Laerte Fernando; DARÓ, Vania. Experimentação animal: histórico, implicações éticas e caracterização como crime ambiental. In: TRĖZ, Thales (Org.). Instrumento Animal: o uso prejudicial de animais no ensino superior. Bauru: Canal 6, 2008.

ORLANS, Barbara. In The Name of Science. Issues in Responsible Animal Experimentation. New York: Oxford University Press, 1993.

PAIXÃO, Rita Leal. Experimentação animal: razões e emoções para uma ética. 2001. 189 f. Tese (Doutorado em Saúde Pública) - Escola Nacional de Saúde Pública Sergio Arouca, Fundação Oswaldo Cruz, Rio de Janeiro, 2001. 
PESSANHA, Vanessa Vieira. Proteção das Gerações Futuras: Um diálogo entre Bioética e Educação. In: CONGRESSO NACIONAL DE PESQUISADORES EM DIREITO, 3., 2014, Curitiba. Anais... Curitiba: CONPEDI, 2014, p. 554-583.

NUNES JÚNIOR, Flávio Martins Alves. Curso de Direito Constitucional. São Paulo: Saraiva, 2019.

RECH, Maya Pauletti. Experimentação Animal: uma abordagem acerca do sofrimento e crueldade, 2013. Disponível em: https://www.pucrs.br/direito/wp-content/ uploads/sites/11/2018/09/maya_rech.pdf. Acesso em: 07 set. 2021.

RYDER, Richard. Experiments on Animals. In: Stanley Godlovitch, Roslind Godlovitch, John Harris Animals, Men and Morals. New York: Taplinger, 1972.

SANTOS, Marcelo Loeblein; GOIS, Marcelo Copetti. Bioética: Algumas Considerações Acerca das Questões Éticas em Pesquisas com Seres Humanos. Revista Direito em Debate, ljuí, Ano XV, $\mathrm{n}{ }^{\circ}$ 27, 28, jan- jun / jul- dez. 2007.

SÉGUIN, Élida. Biodireito. Rio de Janeiro: Lumen Juris, 2005.

SINGER, Peter. Libertação Animal. Trad. Marly Winckler. Porto Alegre: Lugano, 2010. 


\section{dol $10.48209 / 978-65-89949-60-0$}

\section{CAPÍTULO 2}

\section{O DIREITO SISTÊMICO E A APLICAÇÃO DO MÉTODO DA CONSTELAÇÃO FAMILIAR NAS VARAS DE FAMÍLIA}

Isabela Soares de Souza Alexandre Jacob 


\section{INTRODUÇÃ}

O sistema de constelação familiar é um método psicoterapêutico de abordagem sistêmica e subjetiva que busca reconhecer padrões comportamentais familiares, identificando a causa ou a raiz do problema, o qual, vindo à tona, pode ser trabalhado na busca de uma efetiva resolução do conflito vivenciado.

Este método vem sendo utilizado como alternativa de resolução de conflitos no âmbito do Direito de Família, pois muitas vezes a sentença proferida pelo magistrado é insuficiente, não alcança o resultado esperado pelas partes e nem mesmo encerra o conflito existente entre elas. Pode-se observar que frequentemente surgem novas ações com o mesmo objeto. Tal cenário é ainda mais recorrente nos processos que tramitam nas Varas de Família, pois lidam com sentimentos que vão além da legislação.

O Judiciário sozinho não é capaz de resolver conflitos internos, uma vez que uma sentença condenatória tão somente aplica a lei no caso concreto, não sendo capaz de promover a pacificação social. Diante disso, tomando conhecimento do referido tema observa-se que embora o método não seja novo, no Brasil ainda é desconhecido por grande parte da população, entretanto, quando aplicado no âmbito do Poder Judiciário vem apresentando resultados interessantes.

Ao reduzir a judicialização excessiva, a aplicação do Direito sistêmico busca promover a humanização bem como a pacificação social, corroborando com as disposições do Código de Processo Civil e da Resolução n. 125/2010 do Conselho Nacional de Justiça, que estimula a utilização de práticas que proporcionam tratamento adequado dos conflitos de interesse apresentados ao Poder Judiciário.

O tema em comento é de suma importância para o Direito brasileiro, pois visa incentivar o uso dos meios consensuais de pacificação dos conflitos sociais, evidenciando a mediação, buscando com isso reduzir o tempo de tramitação de uma ação no Judiciário. Vale pontuar que por se tratar de uma forma relativamente nova de auxílio na resolução de conflitos, não há vasta literatura sobre 
as constelações familiares, nem mesmo ampla discussão doutrinária. Entretanto, vale à pena examinar as inovações trazidas pela legislação que versa sobre mediação e análise dos resultados já alcançados com a aplicação do método no país.

Neste contexto, a pesquisa visa responder ao seguinte problema: de que forma a aplicação do método de Constelação familiar pode ser uma alternativa para reduzir a sobrecarga de litígios no Poder Judiciário, em especial, nas Varas de Família?

A presente pesquisa possui caráter descritivo e exploratório, de cunho bibliográfico e teve como objetivo analisar o método da Constelação Familiar aplicada na esfera do Direito de Família e suas potencialidades enquanto alternativa na resolução de conflitos. Para atingir esse objetivo, estudou-se a legislação que trata da mediação e métodos de autocomposição para compreender o Direito sistêmico e suas aplicações; conhecer o método de Constelação Familiar e suas peculiaridades; avaliar os resultados obtidos nas serventias que utilizam o método; levantar a opinião de operadores do Direito e Psicólogos acerca da utilização o método.

\section{OS MÉTODOS DE AUTOCOMPOSIÇÃO}

De acordo com Antônio Carlos de Araújo Cintra, Ada Pellegrini Grinover e Cândido Rangel Dinamarco (2020), antes mesmo de o Estado conquistar para si o poder de declarar o direito no caso concreto e promover a sua realização, já se fazia presente o instituto da autocomposição, sendo esta tão antiga quanto à autotutela. Importante destacar que a jurisdição como se vê hoje vem sendo moldada pouco a pouco de acordo com as necessidades de cada período vivenciado pela sociedade, permitindo-se assim dirimir conflitos e promover a pacificação social. Nesse contexto, a autocomposição foi ganhando seu espaço no sentido de que a pacificação é mais importante, independendo do meio adotado para tanto. 
A Lei $n^{\circ}$. 9.099/1995, que dispõe sobre a organização e funcionamento dos Juizados Especiais Cíveis e Criminais têm como princípios: o critério da oralidade, celeridade, economia processual, simplicidade com objetivo primordial de promover solução pacífica das controvérsias e de atender ao final o princípio implícito da pacificação (BRASIL, 1995). A busca da conciliação nos Juizados Especiais, cíveis e criminais são diretrizes dessa busca por pacificações, assim como a realização das chamadas "semanas de conciliação", promovidas pelo Conselho Nacional de Justiça (CNJ).

É importante destacar que no Brasil tem-se observado um incentivo constante à busca da solução pacífica dos conflitos, evitando a cultura do litígio. Todavia, muitos ainda preferem recorrer ao Poder Judiciário ao invés de tentar resolver seus conflitos de maneira pacífica. Vale ressaltar que o $\mathrm{CNJ}$ tem adotado políticas públicas de incentivo a autocomposição. Para essa finalidade foi criada a Resolução $n^{\circ}$. 125 do CNJ, que determina aos Tribunais de todo o país que constituam um quadro de mediadores/conciliadores e criem setores especializados para a atuação desses profissionais (CNJ, 2010).

O Código de Processo Civil de 2015 surgiu com a perspectiva de incentivar a utilização dos métodos alternativos para a resolução de conflitos, adotando como meios para tanto, principalmente, a utilização dos institutos da conciliação e da mediação, tendo por objetivo promover a celeridade às demandas intentadas, visando alcançar uma efetiva prestação jurisdicional.

Vale arrazoar que são formas de resolução de conflitos: a autodefesa ou autotutela; a autocomposição; e a heterocomposição. Segundo Daniel Amorim Assumpção Neves (2020), a autotutela é a forma mais antiga de solução dos conflitos. Por meio da aplicação deste instituto, as próprias partes, por meio da força, realizam a defesa de seus direitos, havendo nesse caso sobreposição de vontades, porque prevalecerão os ditames do mais forte. Tal modalidade é defesa em lei, uma vez que haverá sempre uma parte prejudicada.

Por sua vez, a autocomposição, ainda nos dizeres de Neves (2020), é o meio pelo qual se busca dirimir o conflito pela proposição de acordo, alinhavado 
entre as partes, onde irão existir ganhos e perdas recíprocas, sendo este o ponto de distinção entre o instituto anterior. Ao falar de autocomposição, podem-se identificar três métodos utilizados para solucionar o conflito de interesses, sendo eles a negociação, a mediação e a conciliação.

A negociação é um mecanismo de solução de conflitos caracterizada pela conversa direta entre as partes sem qualquer intervenção de terceiro como auxiliar ou facilitador (NEVES, 2020). Assim, a negociação deve acontecer de modo cooperativo, sendo necessária a separação entre problema-pessoa, a fim de que se avalie somente o conflito objeto da lide, sendo necessário que ambas as partes apresentem propostas que sejam satisfatórias para todos os envolvidos, de modo que nenhuma das partes saia prejudicada após a composição do acordo entabulado.

A mediação, de diferente modo, será constituída pela intervenção de um terceiro que deve ser imparcial no tocante ao conflito posto sob sua análise (NEVES, 2020). Por assim dizer, as próprias partes deverão buscar uma solução adequada para o litígio. Vale destacar que o papel do mediador é de apenas facilitador do diálogo, não podendo este emitir opiniões próprias sobre o conflito.

Já na conciliação, tal qual na mediação, haverá a interferência de um facilitador, no entanto, o conciliador terá voz ativa, podendo propor soluções para que se resolva o litígio (NEVES, 2020). E além, nas Comissões de Conciliação Prévia, o conciliador se utiliza de alguns instrumentos de convencimento e de todas as técnicas de negociação de que for capaz para facilitar a conciliação.

No entendimento de Luiz Antônio Scavone Júnior (2016, p. 9), a heterocomposição "é a solução de conflito pela atuação de um terceiro dotado de poder para impor, por sentença, a norma aplicável ao caso que the é apresentado". Dentro desse instituto existem dois métodos, o jurisdicional, onde haverá todo o deslinde de um processo judicial, sendo este encerrado por sentença proferida por Juiz competente; e o meio arbitral, regulado pela Lei $n^{\circ}$. 9.307/1996, alterada pela Lei $n^{\circ}$. 13.129/2015, caso em que as partes convencionam entre si que, 
havendo um litígio, este será dirimido por um terceiro alheio à relação, nomeado por ambos os litigantes, que também poderão definir quais procedimentos serão adotados, prazos, etc. Ao final, o arbitro proferirá uma sentença que terá a natureza de título executivo judicial (SCAVONE JÚNIOR, 2016).

O Direito brasileiro está em constante mutação, se adaptando dia-a-dia às mudanças sociais. Diante de uma maior complexidade nas relações sociais vivenciadas, somada ao amplo acesso à informação, que proporciona à população vasto conhecimento de seus direitos. Nesse contexto, aumenta-se também o número de ações judiciais propostas para a satisfação de direitos, o que tem sobrecarregado o Poder Judiciário de forma demasiada, gerando uma cultura de litigância que hoje se busca reduzir por meio dos métodos alternativos de resolução de conflitos.

\section{O DIREITO SISTÊMICO E SEUS REFLEXOS}

De acordo com o geógrafo grego Pausânias, que viveu no segundo século, Sócrates foi um dos primeiros filósofos a cultivar o autoconhecimento ao inscrever no pronau do Templo de Apolo em Delfos a máxima "Homem, conhece-te a ti mesmo". Posteriormente, Platão emprega o referido aforismo através do personagem de Sócrates para motivar seus diálogos. Em seus discursos, Platão deixa claro que Sócrates está se referindo a uma sabedoria de longa data. Benjamin Jowett, no século XIX, em sua tradução dos Diálogos de Platão enumerou seis diálogos que discutem ou exploram o ditado de Delfos: Cármides, Protágoras, Fedro, Filebo, Leis, Alcibíades I. Desde então, o homem nunca mais deixou de procurar respostas aos questionamentos da vida (CAPRA; LUISI, 2014).

De acordo com os autores, o pensamento sistêmico contrapõe-se à visão cartesiana, na qual é sustentada a idéia de que a mente se encontra totalmente separada do corpo físico (dualismo mente-corpo, para René Descartes), e que o mundo deve ser observado de maneira desmembrada (CAPRA; LUISI, 2014). Contudo, com o passar dos tempos, pôde-se verificar que a resolução de um 
problema não se dá de forma isolada, deve-se observar aquilo que o envolve, é necessário que haja interação entre as partes.

O pensamento sistêmico desenvolveu-se com as reflexões de biólogos, no início do século XX e rapidamente desenvolveu-se em diversas disciplinas, formulando teorias sistêmicas próprias e adaptáveis a cada modelo conceitual. Quando se fala em pensamento sistêmico, deve-se ter em mente que o "Sistema" está atrelado à inter-relação das partes envolvidas ou a elementos e unidades que compõe uma estrutura organizada. Lawrence Henderson foi pioneiro no uso do termo "sistema" para se referir tanto a organismos vivos quanto a sistemas sociais. Daí em diante, sistema passou a significar um todo.

Entender as coisas sistemicamente significa visualizá-las dentro de um contexto, atentando-se a todos os componentes que a envolvem. O físico Fritjof Capra e o químico Pier Luigi Luisi (2014), enfrentando o tema, asseveram: "quanto mais são estudados os problemas de nossa época, mais se percebe que eles não podem ser entendidos isoladamente. São problemas sistêmicos, o que significa que estão interligados e são interdependentes".

A teoria sistêmica tem caminhado lado a lado com a física quântica, a partir da mudança na visão de mundo, onde passou da concepção linear-mecanicista de Descartes e Newton para uma visão holística e ecológica. No campo do Direito de Família, objeto dessa pesquisa, deve-se vislumbrar a entidade familiar como um "sistema" onde cada membro ocupa o seu devido lugar (OLDONI, 2017). Deste modo, há a necessidade de se compreender o conflito familiar como um todo e que o todo não é a mera soma das partes, mas delas depende.

A expressão "Direito Sistêmico" surge a partir da análise do Direito segundo a ciência das constelações sistêmicas, desenvolvida pelo psicoterapeuta Bert Hellinger e no Brasil, objeto de estudo do magistrado Sami Storch (2010), que conceitua: "trata-se de uma ciência dos relacionamentos, válida para relações humanas, organizacionais e relações jurídicas em geral, uma vez que toda relação constitui um sistema ou se constitui dentro de um". 
Storch verificou que a aplicação desta metodologia promove uma justiça mais humanizada e eficiente. Ele explica:

Uma das bases do direito sistêmico é a consideração pela pessoa e pela bagagem que ela traz (família). Um indivíduo não pode ser tratado isolado, ele tem que ser encarado como um sistema, formado por ele próprio, pelo pai e pela mãe. Se queremos conhecer alguém ou a nós mesmos nós precisamos assimilar a origem desse ser. Todos gostam de ser reconhecidos. Muitas pessoas ingressam com processos na Justiça por conta de um motivo, mas quando é feita a análise mais profunda, é possível verificar que o problema maior é que elas foram desconsideradas pelo outro ou sofreram um gesto de não reconhecimento (STORCH, 2015).

\section{A CONSTELAÇÃO FAMILIAR}

Criada pelo psicoterapeuta Bert Hellinger, a Constelação Familiar é uma psicoterapia desenvolvida por volta da década de 70 do século $X X$, que uniu diversas práticas de terapia alternativa e a filosofia familiar da comunidade Zulu para abordar questões subjetivas do indivíduo, e chegou ao Brasil por volta do ano de 1999.

A teoria da análise transacional de Eric Berne foi uma das bases para o estudo desenvolvido por Bert Hellinger, tal teoria leciona que o ser humano é um indivíduo social, e que se colocado em contato com outra pessoa, algo irá resultar dessa inter-relação. Outra referência para Bert Hellinger foram os estudos da psicoterapeuta norte americana Virginia Satir, que trabalhava com o método das “esculturas familiares” (HELLINGER; HÖVEL, 2007).

A prática divide opiniões - há quem diga que se trata de um método inovador; para outros, de uma pseudociência. De acordo com Hellinger, a constelação familiar é uma forma de descobrir a origem de questões pessoais e origens de problemas que se mantêm presentes nas famílias por gerações através da linhagem familiar. A família é a base para o comportamento humano, e cada ser humano possui um lugar certo na vida e no Universo (HELLINGER, 2007).

Para o autor, a todo o tempo as pessoas seguem determinados padrões e normas para viver em sociedade. No sistema familiar, assim como nas relações 
sociais não é diferente. Hoje é possível observar que as Constelações Sistêmicas têm sido incorporadas ao Poder Judiciário em vários de seus âmbitos, seja na seara cível, criminal, trabalhista, juízo de falência e nas varas de Família.

A Constelação permite que a Justiça ofereça outras soluções ao litígio que não somente a aplicação da lei fria no caso concreto. Busca-se solucionar o problema em si, viabilizando a paz, de forma que o conflito possa ser entendido e dirimido pelas partes, não aplicar a lei para resolver uma situação momentânea (RODRIGUES, 2017).

A aplicação das constelações familiares, de acordo com o Conselho Nacional de Justiça, está alinhavada à Resolução n 125/2010 do órgão, que busca estimular práticas para solução alternativa de conflitos (CNJ, 2010). O sítio eletrônico do próprio Conselho possui notícias que explicam como a constelação familiar é aplicada através de reuniões em grupos, realizadas em salas dos próprios fóruns, onde as partes de vários processos são convidadas a participar de uma reunião de forma voluntária (FARIELLO; 2018a; OTONI; FARIELLO, 2018).

Em contrapartida, as Constelações não foram reconhecidas pelas comunidades científicas e não há, até o momento, estudos que comprovem a sua eficácia. No entanto, o método foi reconhecido pelo Sistema Único de Saúde (SUS), em março do ano de 2018, e encontra-se como uma das 29 terapias alternativas complementares ofertadas pela saúde pública (COLAVITTI, 2018).

O Conselho Federal de Medicina (CFM) posicionou-se contra a utilização do método, assim como membros de Organizações Não Governamentais (ONGs) de direitos das mulheres que contestam a aplicação da constelação familiar na saúde pública e no Judiciário, justamente pela falta de comprovação de eficácia do método (CFM, 2018; GRAVE, 2020).

\section{A CONSTELAÇÃO FAMILIAR NAS VARAS DE FAMÍLIA}

As constelações aplicadas na esfera judicial, assim como na extrajudicial tratam de questões de foro íntimo, por isso, as sessões realizadas são sigilosas. Deste modo, são poucos os casos levados à público, de maneira detalhada. 
Certa feita, em uma sessão conjunta realizada pelo magistrado Sami Storch (2015), na cidade de Valença, Bahia, dentre os aproximadamente 120 presentes, uma mulher foi convidada a expor seu conflito aos participantes. A mulher movia uma ação em desfavor de sua filha de 35 anos, usuária de crack, acometida por transtornos mentais objetivando a sua internação compulsória, uma vez que esta se recusava a realizar tratamento e ameaçava pessoas pelas ruas. O constelador convidou alguns voluntários para representarem os envolvidos no conflito, sendo eles: a mãe, o pai, a filha, o crack e o avô materno - reproduzindo, assim, a dinâmica familiar.

Narra o constelador que o voluntário que simbolizava o crack se posicionou entre as representantes da mãe e da filha, impedindo sua aproximação. A mãe, então falou: "Não, você não vai tocar nela!". Então, observando a dinâmica do sistema o constelador constatou que havia, naquele emaranhado um excluído, e o crack representava esta pessoa. Após algum tempo, cerca de uma hora, a mulher relembrou parte de sua história, antes de sua filha nascer. Narrou que seu pai a obrigou a se casar. Para o constelador foi encontrada a raiz do problema: a relação entre a mulher e seu pai. "Falei que o crack representava, na verdade, um homem", diz ele. "Expliquei que, apesar de ter sido muito difícil para a mãe ter sido obrigada a se casar, somente porque isso aconteceu a sua filha pôde vir ao mundo. Se ela amava a filha, teria que, a despeito de tudo, reconhecer e agradecer o que seu pai fez". A mulher, a seguir, olha para seu "pai" e, emocionada, agradece-o (STORCH, 2015).

O segundo caso trata de um casal que passava por um divórcio litigioso, onde era pleiteada a partilha dos bens adquiridos na constância da união, bem como a regulamentação de guarda, visitas e alimentos em prol da filha do casal. O processo já tramitava há dois anos, pois não havia consenso quanto a nenhum dos pedidos formulados pelas partes. Havia briga quanto à partilha, quanto à fixação dos alimentos, quanto à regulamentação da guarda. 
Realizada a audiência de conciliação, não foi possível a propositura de acordo. Analisando o caso, o magistrado titular da vara, adepto à inclusão das constelações ao Poder Judiciário, vislumbrando que o conflito ia além daquilo que era exposto nos autos propôs ao casal a suspensão do feito, a fim de que estes participassem de uma sessão de constelação familiar. O casal demonstrou interesse e aceitou a proposta. Após cerca de um mês, as partes compareceram ao consultório do constelador/terapeuta indicado pelo juízo. Em um primeiro momento, foi realizada uma breve palestra, onde foram explicados os fundamentos, os princípios e as leis que regem as constelações. Após, foi dado início à sessão. De diferente modo, a sessão, por opção do casal foi realizada com objetos (bonecos), pois não se sentiram à vontade para participar de uma sessão em grupo (OLDONI et al, 2018).

Os participantes foram convidados a posicionar sete bonecos, dois representando o casal, dois representando os pais do cônjuge varão, dois representando os pais do cônjuge virago e o ultimo representando o filho do casal. Dado o posicionamento alinhavado, o constelador pôde observar que o casal não possuía uma dinâmica ideal, uma vez que o cônjuge varão, após o casamento, não tomou o seu lugar como marido, permanecendo intimamente ligado à mãe, o que causou uma desordem em seu casamento. Ao final da sessão que durou cerca de uma hora e meia os representantes foram reposicionados, apontando o padrão ideal. Expõe que diante daquela representação puderam observar problemas e sentimentos que antes não conseguiam enxergar claramente. Passaram a entender e a olhar sua relação familiar com outros olhos, e entender que cada pessoa representa um sistema inteiro e que esse sistema deve ser respeitado (OLDONI et al, 2018).

Atualmente não há qualquer lei que regulamente o modus operandi das constelações no âmbito do Poder Judiciário. Deste modo, pode-se observar a aplicação do método por advogados, juízes, promotores, terapeutas indicados pelo juízo e conciliadores que se consideram capacitados para tanto. 


\section{O PROJETO DE LEI No. 9.444 DE 2017}

Tramita na Câmara dos Deputados o Projeto de Lei n. 9.444/2017 sobre o tema, cujo objetivo é "oferecer a constelação familiar e sistêmica como um recurso a mais à disposição do Poder Judiciário, a qual pode ser empregada antes da mediação e da conciliação e nos indivíduos que estão sob custódia do poder judiciário" (CÂMARA DOS DEPUTADOS, 2021). 0 artigo $1^{\circ}$ do Projeto pontua que o diploma legal tratará de estabelecer "as competências da Constelação Sistêmica na solução de conflitos" e o artigo $2^{\circ}$ a conceitua como uma atividade terapêutica. Defende, ainda, que, em caso algum o magistrado poderá conduzir à dinâmica, uma vez que esta deverá ser realizada por terceiro imparcial, a fim de que não se contamine o julgamento final da lide (OLDONI et al, 2018).

Além disso, enfatiza o PL n. 9.444/2017 que são princípios norteadores da dinâmica: a imparcialidade do constelador; a informalidade; a autonomia da vontade das partes; a busca da resolução dos conflitos e da boa-fé. Ainda, verifica-se que aquele que for considerado hipossuficiente fará jus à concessão do benefício da gratuidade de justiça. Entretanto, o projeto é omisso a tratar de tal temática, uma vez que nada pontua a respeito das custas inerentes do procedimento em comento, sendo impossível apurar o quão oneroso será tanto as sessões realizadas e como/onde elas se desenvolverão.

Ainda no que tange à capacitação dos indivíduos (artigo 10), pode-se observar que o projeto indica que poderá exercer a função de constelador aquele que seja graduado em curso de ensino superior, independentemente da área, desde que tenha realizado curso de capacitação de no mínimo 140 horas, o que é totalmente questionável.

\section{OS RESULTADOS OBTIDOS COM O MÉTODO DA CONSTELAÇÃO FAMILIAR}

De maneira geral, as constelações familiares têm alcançado resultados significativos no âmbito do poder judiciário nacional, em que pese à ausência de comprovação cientifica a respeitos da utilização do método e dos resultados por 
ele alcançados. Na prática seus efeitos podem ser verificados com clareza.

Hoje se pode observar que em 17 Estados da federação foram implementados projetos relacionados ao tema, existindo, inclusive, cursos de aperfeiçoamento e pós-graduação na área de constelação familiar e Direito sistêmico já disponíveis em instituições de ensino superior no país (INNOVARE, 2021).

Dentre os constelados entrevistados foi possível observar que todos eles aprovaram e recomendam a utilização do método, narrando que a sua aplicação foi eficaz e de imenso proveito, uma vez que a constelação busca uma solução rápida, alcançando, na maioria dos casos o fim a que se destinou (STORCH, 2018). É natural que nem sempre os resultados desejados serão obtidos na primeira ou segunda sessão, variando de caso a caso. Lado outro, também é possível encontrar muitos relatos de casos em que o método não alcançou seu fim, causando danos psicológicos aos participantes que se viram obrigados a procurar tratamento psicológico após as sessões realizadas (GRAVE, 2020).

No entanto, é necessário pontuar que assim como em qualquer outro meio de intervenção é preciso se tomar muito cuidado e ter muita ética quando da aplicação da constelação familiar, pois serão trabalhados traumas, que se tocados de maneira superficial ou negligente, ao invés de solucionar o problema poderá dar ensejo a conflitos mais profundos. Assim como na Psicologia, o bom resultado depende do profissional que está atuando.

\section{A PERCEPÇÃO JURÍdICA, PSICOLÓGICA E SOCIAL}

Com objetivo de dar embasamento prático à pesquisa, foi realizado levantamento que teve como meta verificar como uma técnica relacionada a uma matéria ligada à psicoterapia pode ser aplicada no campo jurídico, bem como a visão dos operadores da lei e dos psicólogos quanto à utilização dessa técnica no pelo Poder Judiciário.

Para isso, durante os meses de agosto e setembro de 2021 foram realizadas entrevistas com psicólogos, terapeutas, consteladores, advogados, juízes e 
promotores de justiça. Em um momento posterior foi realizado um questionário a respeito do tema, sendo este disponibilizado pelo Google Forms ${ }^{\circledR}$ e distribuído a 100 pessoas aleatórias, tendo por objetivo verificar o índice de aceitação e conhecimento superficial de parcela da população a respeitos das constelações familiares. Em ambos os casos, o instrumento de coleta de dados foi confeccionado como Termo de Consentimento Livre e Esclarecido, sendo garantido o anonimato dos participantes.

Os resultados obtidos foram controversos, uma vez que não há consensualidade a respeito da aplicação das constelações no âmbito do Poder Judiciário e nem mesmo no campo da Psicologia. Em síntese, dois são os maiores pontos de debate: primeiro, a comprovação científica e a forma de aplicação do método; e segundo, os custos inerentes da aplicação.

Quanto ao questionário, duas perguntas em especial obtiveram respostas conflitantes. Perguntado: considerando que Constelação Familiar é uma forma de descobrir a origem de questões pessoais e origens de problemas que se mantêm presentes nas famílias por gerações através da linhagem familiar; sendo uma forma de terapia alternativa complementar ofertada pela saúde pública e possibilidade de solução de conflitos judiciais familiares. Você conhece ou já ouviu falar sobre Constelação Familiar? 70 pessoas responderam não conhecer ou ter ouvido falar do método, apenas 30 alegaram conhecer.

Em seguida foi apresentada pergunta referente ao Projeto de Lei $\mathrm{n}^{\circ}$. 9.444/2017: atualmente há um Projeto de Lei em tramite na Câmara dos Deputados que objetiva a implementação das constelações na estrutura do Poder Judiciário. Se você fosse um parlamentar; votaria pela aprovação ou pela negativa do referido projeto? 85 pessoas votariam pela aprovação e 15 vetariam o projeto.

Observa-se que, da análise dos resultados alcançados pelas duas questões, pode-se verificar que ao tomarem conhecimento a respeito de um tema aparentemente bom, os entrevistados logo o tomaram como verdadeiramente bom, mesmo sem conhecer ou se aprofundar antes de emitir uma opinião. 
Dentre os operadores do Direito entrevistados (advogados, promotores e juízes) o tema foi visto com bons olhos, mesmo que muitos deles não o conhecessem a fundo a forma de aplicação, apenas relataram ter breve conhecimento acerca dos altos índices de conciliação obtidos. Porém, restou o questionamento referente ao custo, o que na visão de muitos operadores seria um fator que obstaria a difusão do método, vez que para tanto o Judiciário deveria investir na capacitação de profissionais ou realizar novas contratações destinadas a tal fim. Mesmo diante do obstáculo financeiro encontrado, pode-se observar que o tema desperta grande curiosidade e chama a atenção.

De maneira diversa, psicólogos, terapeutas e consteladores entrevistados adotam uma postura cautelosa ao tratar do assunto. Ainda que a constelação familiar venha tomando certa amplitude em segmentos do Direito, para a Psicologia existe a barreira da cientificidade, uma vez que até o momento a eficácia do método não foi devidamente comprovada.

Deste modo, parte da comunidade não admite o uso da constelação uma vez que a Psicologia é por si só uma ciência, e para que formas de a aplicar sejam aceitas devem ser comprovadas pelo método cientifico. Em contrapartida, muitos psicólogos já vêm aplicando o método em seus consultórios tendo em vista que os resultados alcançados são notórios.

No que tange a aplicação das constelações no Poder Judiciário, deve-se sempre se ater ao fato de que o indivíduo deve ter o desejo de participar das sessões, e não ser compelido a tal, o que, para muitos psicólogos é um ponto crítico, uma vez que, quando intimada pelo juiz, a parte pode se sentir coagida, e se ver obrigada a comparecer.

Outro ponto nodal diz respeito à aplicação do método: quem o deve fazer? Atualmente não há uma regra que regulamente a forma de aplicação das constelações no âmbito do Poder Judiciário, podendo esta ser aplicada por juízes, promotores, advogados, defensores públicos, conciliadores terapeutas ou psicólogos. Nota-se que dentre os profissionais citados, por mais que tenham realizado algum curso de capacitação, a maioria deles não passou por estudos 
aprofundados dos vários tipos de traumas aos quais o ser humano pode ser acometido, traumas estes que se tocados de forma indevida podem desencadear diversas reações negativas aparte. Deste modo, assim como em qualquer outro meio de intervenção, a capacitação e o cuidado do profissional que o realizará é de extrema importância para que se alcance o resultado pretendido.

\section{CONCLUSÃO}

A dinâmica das Constelações Familiares possibilita a exteriorização de conflitos internos, ajudando a restaurar o equilíbrio. Este método contribui para que as partes identifiquem a origem de seus problemas e consigam resolvê-los de forma satisfatória, assim como abre espaço para uma Justiça Restaurativa.

Assim pode-se concluir que de fato as Constelações Familiares são ferramentas eficazes na resolução de conflitos de forma pacífica, diante dos resultados alcançados por diversos tribunais. No entanto, é importante dar ênfase a necessidade de regulamentação do tema, especialmente quanto à forma de aplicação do método, uma vez que é de extrema importância que os profissionais envolvidos possuam amplo conhecimento e habilidade para lidar com os traumas aos quais serão expostos. Por fim, reitera-se que é notória a pertinência da aplicação de métodos restaurativos na resolução de conflitos pelo Poder Judiciário, sendo a utilização das constelações um meio hábil a humanizar e reestruturar os vínculos familiares.

\section{REFERÊNCIAS}

BRASIL. Lei $\mathbf{n}^{\circ} . \mathbf{9 . 0 9 9}$ de 26 de setembro de 1995. Dispõe sobre os Juizados Especiais Cíveis e Criminais e dá outras providências. Brasília-DF: Senado, 1995. Disponível em: https://bit.ly/3ayAYD2. Acesso em: 12 set. 2021.

BRASIL. Lei n 13.105 de 16 de março de 2015. Código de Processo Civil. Brasília-DF: Senado, 2015. Disponível em: https://bit.ly/3v7SNSy. Acesso em: 10 set. 2021. 
CÂMARA DOS DEPUTADOS. Projeto de Lei $\mathbf{n}^{\circ} . \mathbf{9 . 4 4 4}$ de 2017. Dispõe sobre a inclusão da Constelação Sistêmica como um instrumento de mediação entre particulares [...]. Brasília-DF: Câmara dos deputados, 2021. Disponível em: https:// bit.ly/2YUkdj8. Acesso em: 13 out. 2021.

CAPRA, Fritjof; LUISI, Pier Luigi. A visão sistêmica da vida: uma concepção unificada e suas implicações filosóficas, políticas, sociais e econômicas. São Paulo: Cultrix, 2014.

CFM. Conselho Federal de Medicina. Nota à população e aos médicos de 13 de março de 2018. Tema: incorporação de práticas alternativas pelo SUS. Brasília-DF: CFM, 2018.Disponível em: https://bit.ly/3AI0cJw. Acesso em: 17 set. 2021.

CINTRA, Antônio Carlos de Araújo; GRINOVER, Ada Pellegrini; DINAMARCO, Cândido Rangel. Teoria geral do processo. 32. ed. Salvador: Juspodivm, 2020.

CNJ. Conselho Nacional de Justiça. Resolução n ${ }^{\circ} 125$ de 29 de novembro de 2010. Dispõe sobre a Política Judiciária Nacional de tratamento adequado dos conflitos de interesses no âmbito do Poder Judiciário [...]. Brasília-DF: CNJ, 2010. Disponível em: https://bit.ly/3axSJCb. Acesso em: 17 set. 2021.

COLAVITTI, Fernanda. O que é constelação familiar, terapia oferecida gratuitamente no SUS. Boa Forma, 23 jun. 2018. Disponível em: https://bit.ly/3IBJDe0. Acesso em: 17 set. 2021.

FARIELLO, Luiza. Constelação familiar: no firmamento da justiça em 16 estados e no DF. CNJ Notícias, 03 abr. 2018a. Disponível em: https://bit.ly/2YKbpN2. Acesso em: 17 set. 2021.

FARIELLO, Luiza. A busca pela paz com a constelação familiar no tribunal do DF. CNJ Notícias, 29 mai. 2018b. Disponível em: https://bit.ly/3BRfgpu. Acesso em: 17 set. 2021.

GRAVE, Janice. Constelação familiar: apologia ao machismo? 11 dez. 2020. Disponível em: https://bit.ly/3iXFIGG. Acesso em: 17 set. 2021.

HELLINGER, Bert. Ordens do amor: um guia para o trabalho com constelações familiares. São Paulo: Cultrix, 2007. 
HELLINGER, Bert; HÖVEL, Gabriele Ten. Constelações familiares: o reconhecimento das ordens do amor. São Paulo: Cultrix, 2007.

INNOVARE. Faculdade Innovare. Curso de Pós-graduação Familienstellen: a constelação familiar original Hellinger ${ }^{\circledR}$ (sítio eletrônico oficial). 2021. Disponível em: https://bit.ly/3FU98j0. Acesso em: 17 set. 2021.

NEVES, Daniel Amorim Assumpção. Manual de direito processual civil. 12.ed. Salvador, Juspodivm, 2020.

OLDONI, Fabiano; LIPPMANN, Márcia Sarubi; GIRARDI, Maria Fernanda Gugelmin. Direito sistêmico: aplicação das leis sistêmicas de Bert Hellinger ao direito de família e ao direito penal. Joinville: Manuscritos, 2018.

OTONI, Luciana; FARIELLO, Luiza. Constelação pacifica conflitos de família no judiciário. CNJ Notícias, 30 abr. 2018. Disponível em: https://bit.ly/3vmljPH. Acesso em: 17 set. 2021.

RODRIGUES, Mithiele Tatiana. O direito através de uma visão sistêmica: uma abordagem da essência do ser através da análise de casos com a aplicação da constelação jurídica sistêmica. Actio Revista de Estudos Jurídicos, Maringá, v. 2, n. 27, 2017. Disponível em: https://bit.ly/3v4WBUQ. Acesso em: 11 out. 2021.

SCAVONE JUNIOR, Luiz Antônio. Manual de arbitragem: mediação e conciliação. 7. ed., rev., atual. e ampl. Rio de Janeiro: Forense, 2016.

STORCH, Sami. O que é direito sistêmico? Direito sistêmico, 29 nov. 2010. Disponível em: https://bit.ly/3lzkDnQ. Acesso em: 11 out. 2021.

STORCH, Sami. Direito sistêmico: primeiras experiências com constelações no judiciário. Revista Filosofia, Pensamento e Prática das Constelações Sistêmicas, São Paulo, n. 4, 2015.

STORCH, Sami. Direito sistêmico é uma luz no campo dos meios adequados de solução de conflitos. Consultor Jurídico, 20 jun. 2018. Disponível em: https://bit. ly/3awRmUv. Acesso em: 11 out. 2021. 


\section{dol $10.48209 / 978-65-89949-60-3$}

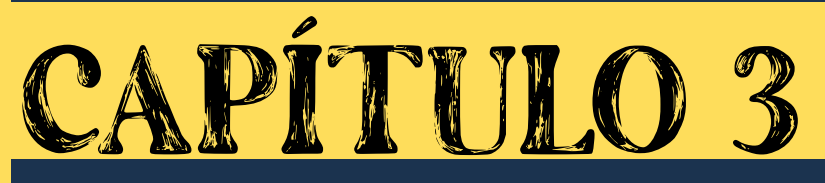

\section{PARA ALÉM DA}

FAMÍLIA TRADICIONAL:

ABERTURA DO CONCEITO

E POLÍTICAS FAMILIARES

NO DIREITO BRASILEIRO

Lucas Melo Rodrigues de Sousa 


\section{INTRODUÇÃO}

Constata-se que atualmente não podemos falar "a família", como se houvesse um único modelo de integração familiar padronizado universalmente. Existem inúmeras formas: biparentais, nucleares, reconstituídas etc. Se antes o casamento era a base que definia a união entre duas pessoas, ele não pode ser mais considerado como tal. O aumento nos divórcios, famílias monoparentais, gays e a popularidade da coabitação demonstra a plasticidade das relações. O respeito às diversas modalidades familiares é um pressuposto constitucional. Conclui-se que os direitos fundamentais possuem uma perspectiva garantista baseada na dignidade da pessoa humana. São direitos representativos que impõe ao Estado o dever de observar as pretensões advindas da soberania popular, fluindo sua aplicação material e formal independentemente de limites temporais. Constituindo um núcleo inviolável que protege todos os indivíduos dentro de um determinado Estado soberano.

\section{FAMÍLIA HOMOAFETIVA}

\section{Histórico}

O termo homossexualidade surgiu em 1860 com intuito de atribuir aos relacionamentos uniformes um tom depreciativo. Segundo Maria Berenice Dias o termo (2013, p. 31), "exprime tanto a ideia de semelhante, igual, análogo, ou seja, homólogo ou semelhante ao sexo que a pessoa almeja ter, como também significa a sexualidade exercida com uma pessoa do mesmo sexo".

Na Grécia Antiga, era comum um homem adulto ter relações sexuais com um jovem. Nessa concepção, Dover (2007) apresenta o filósofo grego Sócrates, o qual era adepto ao amor homossexual e afirmava que o coito anal correspondia a melhor forma de inspiração. A visão do filósofo quanto ao sexo heterossexual era a de que tal servia apenas para procriar. Para a educação dos jovens atenienses esperava-se que os adolescentes aceitassem a amizade e os laços 
de amor com homens mais velhos com intuito de absorver suas virtudes e seus conhecimentos de filosofia.

A ignorância do assunto permeou até a Idade Média onde a Igreja Católica transcende seu poder em diversas áreas. De forma soberana difundiu seu pensamento de que os atos sexuais eram unicamente meios de perpetuação da humanidade e em diversos momentos castigou aqueles que o praticavam com outros fins. Incumbe destacar a frase contida no livro bíblico Levítico (18:22): "Não te deitarás com homens, como fazes com mulheres: é abominação". Mudanças enormes ocorreram desde então, em menor escala no campo religioso. (DIAS, 2013)

A concepção abordada fortemente na Idade Média passou a considerar a homossexualidade como uma comorbidade. A perversão e traços biológicos eram vistos como capazes de degradar todo o círculo social promovendo-se intenso tratamento psicológico. Fruto do Cristianismo, tratamentos como terapia de choque, lobotomia e castração foram propostos. A exclusão da homossexualidade como doença mental foi feita pela Organização Mundial da Saúde apenas em 17 de maio de 1990 e ratificada em 1992. (GIDDENS, 2016)

Os valores atribuídos a homossexualidade fizeram com que diversos jovens fossem expulsos de seus lares em virtude da negação familiar. A busca por empregos era inútil, pois na maior parte das vezes o único emprego destinado aos homossexuais era a prostituição e exploração sexual em geral Para uma convivência relativamente pacífica era necessário o isolamento desses grupos em tribos específicas como em Stonewall, mas ainda assim eram vítimas de violência. Eram perseguidos em maior intensidade pela polícia os homens e mulheres com vestígios a figura do gênero oposto, acreditava-se que dessa forma haveria uma maior visibilidade da então considerada doença. (SILVA E CAEIRO, 2015)

Em contrapartida a esse movimento temos a Revolta de Stonewall onde diante da violência policial gritos como "gay power" e "We Shall Overcome" acendeu uma grande revolução para a concessão dos direitos civis à comuni- 
dade gay. Durou cerca de cinco dias em movimentos de intensidades distintas, atualmente é celebrado anualmente. (SOUSA, 2021)

Quanto a batalha de Stonewall:

Stonewall - Em referência ao bar "Stonewall Inn", Em Nova lorque, nos Estados Unidos, é conhecido como um marco na luta pelos direitos LGBT, onde em 28 de junho de 1969, ele foi palco de uma forte reação da comunidade LGBT A uma intervenção policial de rotina no local, em um tempo em que ser LGBT não era algo socialmente aceito. A data é hoje celebrada internacionalmente como "Dia do Orgulho LGBT". A luta, que em 28 de junho de 1969 ficou evidente nos Estados Unidos, perpassa hoje os vários países e fóruns multilaterais. (TERTO; SOUZA, 2015, p. 123)

É uma proeminência que todos os direitos alcançados a esta unidade familiar prosperaram em seus primeiros passos desse intenso movimento. A título de exemplificação a legalização da homossexualidade no Reino Unido foi em 1967, a primeira união homoafetiva foi reconhecida pela Dinamarca em 07/07/1989 e apesar do Brasil ter sido um dos países pioneiros quanto a descriminalização, hoje é o país com maior incidência de crimes contra a comunidade gay. (GIDDENS, 2016)

Como se a homossexualidade fosse "contagiosa", cria-se uma grande resistência em demonstrar simpatia para com os sujeitos homossexuais: a aproximação pode ser interpretada como uma adesão a tal prática ou identidade, portando uma questão social. Várias pessoas não gostam de homossexuais, pois aprenderam no período de criação de sua personalidade que a homossexualidade é um comportamento não aceito. (FARIA e MARIA, 2009)

É evidente que apesar da evolução no que diz respeito a direitos básicos e fundamentais a luta ainda é árdua. (GIDDENS, 2016) aponta que a constante luta da comunidade gay é evidente nas minúcias do que a heterossexualidade colocou no mapa de forma simples: personagens gays em filmes e teatro inicialmente só eram inseridos em tom de deboche, pontua ainda sobre as posições diversas no mundo globalizado onde Estados Soberanos permitem uma vida existencialmente digna e igualitária quanto outros um status mediano e por exceção a exclusão total. 


\section{Reconhecimento Estatal}

Atualmente muito se discute sobre direitos humanos, contudo tal expressão exige que saibamos elucidar em que consiste tais direitos, porque são essenciais e articulados como fundamentais, pois nem sempre estão em concordância com a concepção pessoal dos indivíduos. Não é de ciência geral a garantia de determinados direitos, tampouco que devem ser respeitados e prestados pelo Estado.

Importante inicialmente compreender o significado do termo direitos humanos, estes são valores universais, em todos os tempos e sociedades que possibilitam a um indivíduo afirmar sua condição humana e se desenvolver integralmente abrangendo aspectos biológicos, psicológicos, econômicos, sociais, culturais e políticos. São inerentes a toda coletividade e servem para resguardar todos os homens. É um instrumento contra todo tipo de violência e garantia da preservação da dignidade independente de nacionalidade, sexo, etnia, classe social, crença religiosa, opção política e convicção moral. (NOVELINO, 2020)

A discussão quanto ao fundamento dos direitos humanos se baseia em um debate sobre a natureza e a razão de ser de tais direitos. Um argumento quanto a razão de ser destes é cuidar, resguardar e promover humanidade, impedindo assim que o ser humano seja coisificado. É uma fonte que visa justificar o valor e a necessidade desses direitos ainda que não haja uma fundamentação universal e absoluta, tendo em vista que a expressão pode receber diferentes significados ao longo do tempo e espaço, mas existe uma ideia central baseada na dignidade da pessoa humana.

O problema grave do nosso tempo, com relação aos direitos humanos, não é mais o de fundamentá-los e sim protegê-los, principalmente em virtude dos desafíos enfrentados em virtude de diversas culturas, hábitos, convenções e costumes de inúmeras sociedades, até porque um fundamento seria incapaz de refletir as múltiplas noções e essência do homem. Talvez seja adequado ponderar que o grande desafio da questão é o caráter jurídico, tendo em vista que o 
Estado deve prover medidas para que tais direitos não sejam violados, os direitos humanos só possuem eficácia definitiva quando são vivenciados, a necessidade de praticá-los já demonstra um motivo e razão de ser. (BOBBIO, 1982)

Ao longo do tempo muitas tentativas foram feitas para justificar a existência dos direitos humanos e fundamentá-los, (LOCKE, 1988) já anunciava a opinião de que o homem espontaneamente possui direito à vida e a igualdade de oportunidades, tal preceito é seguido pelo pensamento de (ROUSSEAU, 1985) que apresenta a afirmação de que todos os homens nascem livres e iguais, possuindo direitos inatos e indispensáveis a sua sobrevivência digna, tal ideia imerge em razão do homem ser um ser com sensibilidade capaz de se relacionar com seus semelhantes.

O fundamento dos direitos humanos está vinculado à qualidade da dignidade da pessoa humana, sendo o valor que confere humanidade ao sujeito. Essa ideia busca garantir a autonomia e liberdade, sendo todo ser humano possuidor de um valor essencial, o homem é considerado como um fim em si mesmo e jamais como mero instrumento para realização de algo. A dignidade é um valor incondicional, imensurável e insubstituível e não admite equivalente. (KANT, 1980)

Apesar da conclusiva importância da fundamentação, parece claro que nem sempre podemos fazê-lo com segurança. Não é fácil definir de maneira ampla, satisfatória e inquestionável, podemos ainda até saber o conceito de dignidade, porém nem sempre somos capazes de externalizá-lo, todavia ainda que confuso é possível perceber quando ela é violada. Zelar e promover a dignidade humana é o bastante para tornar nossa vida social menos injusta e violenta.

Por muito tempo a ideia de dignidade se restringia na crença divina, isso é, que todo ser humano é criado à imagem e semelhança de Deus. Ainda que defendida atualmente, é majoritário que a dignidade seja concebida em virtude da racionalidade do homem. É essa faculdade que funda a autonomia da sua vontade e a liberdade que orienta sua ação no mundo. O homem é concebido como o único ser dotado de vontade, sendo capaz de agir de forma livre para controlar 
seus desejos e também suas emoções. O homem não seria um animal racional se não fosse afetivo, usamos nossos sentimentos em prol dos semelhantes e da conquista de uma vida social justa e harmoniosa.

Conclui-se que todos os homens são dotados da mesma dignidade, mas isso não evita que determinados indivíduos sofram violações. Por isso falar em dignidade universal pode parecer uma ideia vaga, já que os indivíduos pertencentes a determinado grupo social possuem proteção em êxito e outros não. $O$ respeito, a garantia e a promoção da dignidade são um processo que está sujeito a recuos e fracassos. Por isso, tal tema deve ser discutido e presente no cotidiano das pessoas.

O homem é um ser passível de ser melhorado e superar instintos egoístas e prejudiciais à sociedade. Por isso é sempre importante defender a educação fundamentada em direitos humanos, devendo o homem ser preparado para vida em sociedade, tal processo pode promover valores como solidariedade, justiça e respeito mútuo, pois a realização de tais valores permite a aptidão de viver com dignidade. Dessa forma propõe-se as seguintes medidas:

\section{Quadro 1 - Recomendações}

Homofobia (assim como sexismo, racismo, classismo, apetite e outros) deve ser considerada uma questão estrutural.

Uma estratégia claramente apoiada é necessária contra a homofobia e o sexismo em políticas educacionais e currículo nacional.

Há necessidade de articular e fortalecer a intersetorialidade entre políticas educacionais contra a homofobia com outras políticas públicas, como redução da pobreza, trabalho, saúde e outros

Devem ser desenvolvidas políticas de longo prazo contra a homofobia.

É necessário reconhecer e desenvolver estratégias para enfrentar a resistência local à política de implementação.

Fonte: Elaborado pelo autor. 


\section{Da educação}

As primeiras iniciativas destinadas a apoiar a diversidade sexual e combater a discriminação sexual e homofobia no sistema escolar brasileiro podem ser rastreadas em meados da década de 1990, quando diretrizes sobre educação sexual foram adotadas como um currículo nacional transversal pelo Ministro da Educação. Posteriormente uma série de iniciativas estaduais e municipais floresceu com diretrizes para lidar com a discriminação contra gays, lésbicas, transexuais. Entre 2003 e 2010 uma série de diretrizes de políticas federais foram executadas que atendiam às necessidades e direitos dos LGBT.

Feministas e educadoras sexuais foram definitivamente os principais atores por trás dos primeiros movimentos de iniciativas de educação sexual, mas as múltiplas propostas que surgiram na década de 1990 e 2000 no reino da educação e sexualidade não podem ser totalmente desconectadas da longa trajetória e aspectos virtuosos da resposta brasileira ao HIV/aids no enfrentamento discriminação contra gays, travestis, mulheres transexuais e profissionais do sexo (Parker 1993; Galvão 2002).

Em contraponto ao discurso científico predominante na década de 1980, a AIDS não se configura apenas como uma pandemia biomédica. Constitui-se também em uma pandemia multidisciplinar, de caráter econômico, jurídico, social, moral e linguístico.

Não obstante o avanço farmacológico ter proporcionado melhor qualidade de vida aos portadores do vírus, o preconceito e estigma são empecilhos para que o soropositivo (aquele que possuir anticorpos para o antígeno do HIV) leve uma vida "normal" como um cidadão médio. (SOUSA, 2021).

Fazendo-se positivado o direito à saúde ele se torna um comando constitucional de escopo social. É fruto da segunda dimensão de direitos fundamentais e por essa razão deve ser garantido através de prestações positivas do Estado. (SOUSA, 2021). 
Assim, segundo Bonavides (p. 20, 2020) "Os direitos fundamentais de segunda geração são os direitos sociais, culturais e econômicos, bem como os direitos coletivos ou de coletividades, introduzidos no constitucionalismo das distintas formas de Estado Social."

A exemplo das medidas adotadas pelo Estado Democrático de Direito temos: Profilaxia pré-exposição (PrEP) e em consonância a Profilaxia pós-exposição (PEP).

\section{Quadro 2 - Prep e PEP}

\begin{tabular}{|c|c|}
\hline PrEP & PEP \\
\hline $\begin{array}{l}\text { Em síntese, a estratégia implica na } \\
\text { ingestão diária de medicamentos } \\
\text { antirretrovirais para prevenção ao } \\
\text { HIV, por pessoas que não possuem } \\
\text { o vírus no organismo, mas estão em } \\
\text { situações de potencial exposição. } \\
\text { Implantada no Sistema Único de } \\
\text { Saúde brasileiro, a PrEP desafia as } \\
\text { ações de gestão no âmbito dos } \\
\text { serviços públicos de saúde. }\end{array}$ & $\begin{array}{l}\text { Como profilaxia para o risco de infecção } \\
\text { pelo HIV, a PEP tem por base o uso de } \\
\text { medicamentos antirretrovirais com o objetivo } \\
\text { de reduzir o risco de infecção em situações } \\
\text { de exposição ao vírus. } \\
\text { Trata-se de uma urgência médica e deve } \\
\text { ser iniciada o mais rápido possível - } \\
\text { preferencialmente nas primeiras } \\
\text { duas horas após a exposição de risco e no } \\
\text { máximo em até } 72 \text { horas. A profilaxia deve } \\
\text { ser realizada por } 28 \text { dias e a pessoa tem } \\
\text { que ser acompanhada pela equipe de saúde, } \\
\text { inclusive após esse período realizando } \\
\text { os exames necessários. }\end{array}$ \\
\hline
\end{tabular}

Adaptado de Sousa (2021)

Por outro lado, o incentivo à diversidade sexual e programas anti-homofobia que caracterizaram o cenário político em 2000 foi decididamente o resultado da força crescente do ativismo pelos direitos LGBT e tornado possível pela abertura precoce da administração (sob o Partido dos Trabalhadores) às suas reivindicações. Um ponto de viragem nesta trajetória foi o anúncio do programa 
Brasil Sem Homofobia (BSH) em 2004, que cobriu uma ampla gama de áreas de política, incluindo saúde, educação, trabalho, justiça e segurança pública.

A principal estratégia educacional definida pelo programa Brasil sem homofobia foi fornecer suporte para o desenvolvimento e implantação de cursos e oficinas para professores da rede estadual sobre o respeito à diversidade sexual e a prevenção da homofobia. Eles ofereceram teoria e informações sobre gênero e preconceito sexual, discriminação, homofobia e seus efeitos sobre a cidadania e os direitos humanos. As políticas viam as escolas como uma estratégia chave local para a promoção da transformação social e cultural. Esta linha de trabalho estava sob a cargo do Ministério da Educação. Um fundo foi estabelecido para que universidades, organizações não governamentais (ONGs) e instituições pudessem se inscrever para receber subsídios e desenvolver os cursos.

É evidente, que a tentativa do Brasil de combater a discriminação e apoiar a diversidade sexual em seu sistema educacional não se traduziu em benefícios reais para os principais destinatários dessas políticas. Isso é particularmente claro nos altos níveis de evasão escolar entre travestis que sofreram violência homofóbica na escola. Um conjunto de ramificações negativas para a população LGBT decorre da marginalização social, econômica e educacional ligada particularmente às pessoas LGBT pobres.

Mello et al. (2012) realizaram uma avaliação completa dos programas agrupados no Brasil Sem Homofobia e concluíram que, embora bem intencionados, eles foram comprometidos por vários fatores. Uma ressalva principal era a falta de um bom financiamento, outro aspecto destacado nas análises foi que os vários componentes do programa não foram além de esparsos e iniciativas locais fragmentadas que não tinham o potencial para iniciar e sustentar a longo prazo a mudança social. Em sua opinião, os vários programas sob a égide do BSH nunca se tornaram componentes integrantes das políticas públicas estruturais destinadas a reduzir a pobreza e a exclusão. 
Em relação ao componente educação especificamente, Mello et al. (2012) lista alguns pontos positivos de impacto dos cursos promovidos pelo Ministério da Educação/SECADI como os do Gênero e Diversidade na Escola (GDE, Gênero e Diversidade na Escola), particularmente no que diz respeito à importância de cursos e workshops para professores e funcionários de escolas. Mas eles também observam que, em geral, os programas promovidos pelo Brasil Sem Homofobia não foram capazes de recrutar e vincular professores e outros funcionários das escolas, a fim de inibir a discriminação e a homofobia durante um período sustentado.

Tanto Mello et al. (2011) e Irineu e Froemming (2012) observam que a inclusão da diversidade sexual na educação e as diretrizes da política costumam ser limitadas no tempo e quase nunca propõem e implementam programas permanentes. Mello et al. em particular, observa que os processos de solicitação de concessão tiveram problemas de continuidade. Eles sublinham a frágil ou total ausência de coordenação entre os programas educacionais desenvolvidos no âmbito do Brasil Sem Homofobia e outras políticas públicas estruturais para a redução da pobreza, em particular o Bolsa Família (que incentiva os filhos de famílias pobres a permanecerem na escola), ou mesmo políticas destinadas a reduzir a violência de gênero ou a promover o respeito pelos direitos humanos.

Em 2010, Mello et al. identificou a crescente resistência representada por forças religiosas dogmáticas como um obstáculo chave para a implementação das estratégias educacionais definidas pelo Brasil Sem Homofobia e o Plano Nacional de Políticas Públicas LGBT.

Autores conservadores, pressionaram diretamente o Ministério da Educação e a Presidência da República. O próprio Gabinete suspendeu a distribuição planejada nas escolas de material educacional produzidos sob o patrocínio do Ministro da Educação como parte do programa de promoção da diversidade sexual. A própria presidente Dilma Rousseff decidiu então que a distribuição seria 
cancelada. O fato de ela ter aparecido na TV para anunciar sua decisão revela como a questão se tornou crítica em termos de política de alto nível.

Outro retrocesso em relação às questões de sexualidade no sistema escolar foi que os Ministérios da Saúde e Educação (também sob pressão conservadora) decidiu contra a instalação de preservativos distribuídos nas escolas secundárias. No Carnaval 2012, campanha de prevenção ao HIV destinada a jovens homens que fazem sexo com homens também foi suspensa. Então no início de 2013, a distribuição de livretos escritos em formato de cartoon para informar sobre HIVIAIDS, prevenção, gravidez na adolescência e medidas contra a homofobia voltadas para o ensino secundário nas escolas também foram canceladas.

Em todos os casos, o pessoal técnico dos ministérios tinha anteriormente aprovado os materiais. A retirada do material educativo contra a homofobia (2011) foi amplamente criticada. Politicamente, esse momento gerou uma onda de expectativas entre ativistas e apoiadores sobre a evolução dos direitos LGBT. Essas expectativas tinham alimentado o tradicional apoio do Partido dos TrabaIhadores a vários direitos humanos demandados

No entanto, é importante notar que a resistência conservadora à implementação de programas relacionados à sexualidade não é recente nem atribuída exclusivamente às pressões de os evangélicos. Na década de 1990, a hierarquia católica criticou abertamente a distribuição gratuita de preservativos e a abertura à diversidade sexual que nortearam a resposta brasileira ao HIVIAIDS.

A importância do combate à homofobia no Brasil é incontestável, dada a alta incidência de violência homofóbica e como ela impacta diretamente no acesso aos direitos humanos básicos, como Educação. É necessário, portanto, entender que dada a extensão da homofobia no estado do sistema escolar, as restrições que limitam a discussão do problema afetarão necessariamente a capacidade dos alunos de aprender, se envolver e participar quando diretamente afetados pela discriminação, estigma e violência com base na sua sexualidade. Este impacto negativo se traduz em barreiras ao emprego e, portanto, se correlaciona 
com indicadores socioeconômicos baixos que vinculam pobreza com baixos níveis de educação, muitas pessoas LGBT param de frequentar as escolas. O trabalho para este grupo como já exposto é então limitado ao setor informal com a precariedade que acompanha sistematicamente sexismo, racismo e outras formas de preconceito e discriminação que comprometem o nível socioeconômico e de igualdade.

Quando as políticas públicas de educação e sexualidade não são efetivamente implementadas, esta ausência terá um impacto negativo na sala de aula que continua a ser um espaço estratégico para aprendizagem moral e ética e de mudança social: espaço onde os debates públicos podem florescer e onde a sua implementação a longo prazo pode ser enraizada. Os sistemas escolares apresentam uma oportunidade para o desmantelamento ativo sobre essas formas intersetoriais e sistêmicas de desigualdade.

Além disso, as intervenções destinadas a prevenir e reduzir a discriminação e homofobia nas escolas terão um impacto positivo nas taxas de violência, em particular no caso de espancamentos e homicídios de pessoas LGBT.

Desigualdade social, discriminação persistente de pessoas que não se conformam com o gênero e a homofobia prejudica os direitos humanos e também é um fator subjacente à pobreza e à desigualdade.

O Relatório da Organização Internacional do Trabalho (OIT) (2011) concluiu que a desigualdade, a insegurança e a exclusão são alimentadas pela discriminação. Eles argumentam que a não discriminação e a estabilidade social é fundamental, especialmente em tempos de adversidade econômica. Eles também mencionam estudos que mostram que se o efeito da discriminação de gênero sobre os níveis salariais for eliminado no Brasil, a pobreza diminuiria em uma faixa de dez por cento. Raciocínio semelhante pode ser desenvolvida em relação a outras formas de exclusão e discriminação, incluindo aquelas com base na orientação sexual e identidade de gênero. Em outras palavras, a homofobia 
deveria ser adicionada à lista de fatores que sustentam a desigualdade social e econômica estrutural.

Os efeitos dessas dificuldades e resistência dos religiosos pode ser visto no silenciamento das medidas contra a violência homofóbica nas escolas, políticas ineficazes e esparsas, e a urgência hierárquica das necessidades, onde a homofobia (assim como o sexismo) é visto como menos importante.

Esses aspectos são destacados em estudos relacionados (Mello et al. 2012) que avaliaram direitos e políticas públicas em uma série de áreas, como educação, segurança, trabalho, assistência social e saúde. Essas políticas públicas foram consideradas frágeis, inconsistentes e inexistentes em muitos setores, apesar da origem dessas políticas em planos nacionais, como o Brasil sem Homofobia, o Plano Nacional LGBT e o Programa Nacional de Direitos Humanos.

\section{Suicídio}

Nos últimos anos, vimos um número trágico de adolescentes gays, acabando com suas próprias vidas depois de sofrer bullying anti-gay.

O suicídio é a terceira causa de morte entre adolescentes, e os adolescentes gays têm 4 vezes mais probabilidade do que os adolescentes heterossexuais de tentar o suicídio. Além disso, a dor que os adolescentes gays sentem quando são provocados afetam outras pessoas ao seu redor. Nesta fase os adolescentes sentem uma forte necessidade de se encaixar e, quando veem um estudante gay sendo intimidado por alguma "diferença" percebida, eles se preocupam que suas próprias diferenças - e todos nós as temos - serão alvo de valentões. (GIDDENS, 2016)

Muitos pais acham difícil discutir a sexualidade com seus filhos adolescentes, mas a discussão é crucial para que os filhos desenvolvam uma autoestima saudável, abracem suas próprias diferenças e aceitem o que é diferente dos outros. 
Aqui estão algumas informações que os pais devem considerar:

Quadro 3 - Adolescência e suicídio.

Todos os adolescentes querem ser "normais" e se encaixar com seus colegas, portanto, diferenças na orientação sexual podem atrair assédio e rejeição. Como pais, não importa em que se acredite (com respeito à sexualidade, religião, cultura, política), somos responsáveis pelo comportamento de nossos filhos e precisamos ensiná-los a serem tolerantes.

Pais, professores e todos os adultos atenciosos precisam ser sensíveis aos adolescentes que exibem sentimentos de tristeza, inutilidade, desesperança, ansiedade , irritabilidade, rejeição e raiva - Todos os sintomas de depressão , que são vivenciados pela maioria dos adolescentes que tentam ou concluem suicídio. Alguns pais assumem que se eles são tolerantes com diferentes orientações sexuais, os seus filhos não são afetados pela enxurrada de mensagens sugerindo que é anormal ou imoral para ser gay. Infelizmente, a retórica anti-gay tem uma força extraordinária e insidiosa na paisagem cultural, e os adolescentes gays são particularmente vulneráveis. Os pais de adolescentes gays às vezes são "os últimos a saber" que um problema está se formando.

É fundamental, iniciar uma conversa com os filhos, antes que eles entrem na puberdade, para discutir sentimentos sexuais e tolerância às diferentes orientações sexuais. Se o adolescente está secretamente se sentindo culpado ou envergonhado dos pensamentos sexuais que ele ou ela está tendo, você precisa saber disso para que possa garantir que não há nada de errado com os diferentes pensamentos sexuais, ou a sexualidade em geral. Adolescentes que se sentem desconfortáveis com sua sexualidade geralmente sofrem de baixa autoestima, por isso é essencial que combatamos seus sentimentos de angústia com uma mensagem muito positiva de aceitação e amor. Nossos adolescentes precisam entender que, embora às vezes discordamos deles - ou simplesmente tenhamos sentimentos diferentes - respeitamos suas crenças e diferenças.

Fonte: Criado pelo autor. 


\section{Do casamento}

Constata-se que o casamento é um contrato bilateral e solene, sendo assim um dos negócios jurídicos mais importantes do direito civil é formal e tem fulcro no direito das famílias, por meio do qual duas pessoas se vinculam através de uma relação jurídica típica e pública que é a relação matrimonial, conforme o artigo 1.511 do Código Civil "O casamento estabelece comunhão plena de vida, com base na igualdade de direitos e deveres dos cônjuges". Apesar de ser um assunto atualmente consolidado pelo Supremo Tribunal Federal e não havendo óbice relativo a uniões homoafetivas, pois sendo o casamento a forma mais abrangente que o Estado protege a família e se são múltiplos os arranjos familiares reconhecidos pela Constituição Federal não poderiam os casais homoafetivos serem excluídos de tal narrativa.

Registra-se que a vigente Carta Magna traz em seu bojo o seguinte texto (BRASIL, 1898) homens e mulheres são iguais em direitos e obrigações, a família, base da sociedade, tem especial proteção do Estado, para efeito da proteção, é reconhecida a união estável entre o homem e a mulher como entidade familiar, devendo a lei facilitar sua conversão em casamento. Evidencia-se que a intepretação constitucional deve ser feita levando em conta as peculiaridades que singularizam seus preceitos, o método normativo-estruturante se impõe como uma intepretação entre o texto e a realidade, a norma não compreende apenas o seu texto literal é necessário uma abordagem social e histórica, não havendo discriminação imotivada.

A Constituição Federal concede proteção da família, independe da celebração do negócio jurídico do casamento e agregou diversos tipos familiares, meramente exemplificativo é a disposição do caput do art. 266 , não se admitindo que haja exclusão em virtude de uma cláusula geral, sendo a união permitida a todos.

Percebe-se que toda Constituição ao manifestar pretensões sociais de sua era, mesmo quando omissa, provoca efeitos. Ao dizer que homens e mulheres são iguais em direitos e obrigações nos parece que a Constituição Federal com 
intuito protetivo diante de eras de desigualdade de gênero, apenas deseja que haja tratamento igualitário entre estes em seus diversos negócios jurídicos incluindo uniões afetivas e nesse mesmo sentido a especificação entre homens e mulheres como entidade familiar é apenas uma regra geral exemplificativa, sendo apenas um reforço a finalidade primária do casamento onde deve se imputar amor físico e comunhão plena e igualitária, não sendo características do casamento exigência de sexos divergentes.

Salienta-se que a omissão do legislador constituinte como uma suposta vedação ao fato em plena Constituição Cidadã que promove igualdade, dignidade plena, prevalência dos direitos humanos, vedação a tratamentos degradantes, segurança, inviolabilidade da intimidade, vida privada e honra das pessoas através de uma interpretação em unidade que busca impedir eventuais contradições havendo uma necessidade de uma coesão normativa e social levando em conta a unidade constitucional, não cabendo discriminação afetiva de acordo com Lei de Introdução às Normas do Direito Brasileiro, em face de silencio do legislador deve o juiz se valer da analogia, costumes e dos princípios gerais do direto.

A equiparação da união uniforme permite que a união afetiva e sexual duradoura dos casais homoafetivos e ausência de vínculos formais permita a aplicação analógica da união estável que será convertida em casamento de forma otimizada e mais célere. E como previsto no diploma normativo maior (BRASIL, 1988) o Estado assegurará a assistência à família na pessoa de cada um dos que a integram, criando mecanismos para coibir a violência no âmbito de suas relações ainda.

Sendo múltiplos os arranjos familiares e se duas pessoas cumprindo o dever de assistência e respeito mútuo com a finalidade de constituir um lar independente do sexo, não há de falar de uma política retrógada e discriminatória, nada deve imperar se não o respeito e dignidade humana universalmente, a falta de efetiva proteção aos casais homoafetivos não irá fazer com que tal união ainda que informalmente desapareça, o repudio de movimentos conservadores não pode limitar e retroagir o reconhecimento familiar homoafetivo, há uma previsão 
expressa quando ao instituto da proibição do retrocesso, não cabendo ignorar minorias, os casais homoafetivos não agridem a ordem social, não havendo objeção para que estas relações sejam reguladas pelo direito das famílias e não pelo campo do direito das obrigações com caráter puramente comercial, pois a família se pondera principalmente pelo princípio da afetividade.

\section{Da adoção}

A legislação nacional define adoção como uma forma de filiação civil que atribuiu a qualidade de filho a um terceiro como se consanguíneo fosse sendo ato irrevogável, seus efeitos são previstos em lei mediante a requisitos previstos pelo legislador que não são passíveis de negociação. Maria Berenice Dias (2013, p.434) conceitua adoção como "modalidade de filiação constituída no amor, gerando vínculo de parentesco por opção".

As respostas parecem encontrar-se como o princípio da dignidade humana (art. $1^{\circ}$, III da Constituição Federal) é pilar necessário do Estado Democrático de Direito e da Declaração dos Direitos do Homem e do Cidadão que reforça em âmbito global "todos os homens nascem livres e iguais em direitos e dignidade" (Organização das Nações Unidas - ONU). Assim o direito à adoção a casais homoafetivos deve ser reconhecido globalmente como já é em nosso país. A Constituição prevê o bem de todos, sem preconceitos, nessa situação adotante e adotado estão em um prisma de uma relação de bem comum e desenvolvimento integral, a moral sexual conservadora do passado não pode rondar para que haja cometimento de injustiças, pois o direito, como instrumento de pacificação social e poder, não deve excluir os laços afetivos e sociais em virtude da dinâmica do direito que seja correspondente aos nossos tempos.

Destaca-se o que preveem FARIAS e MAIA, 2009. p.59:

O desenvolvimento da criança não depende do tipo de família, mas do vínculo que esses pais e mães vão estabelecer entre eles e a criança. Afeto, carinho, regras: essas coisas são mais importantes para uma criança crescer saudável do que a orientação sexual dos pais. 
A multiparentalidade é possível, dessa forma, podendo constar o nome de dois pais na certidão de nascimento da criança ou do adolescente. Novamente, em razão do princípio da vedação ao retrocesso não há razão para que os direitos dos casais homoafetivos no que diz respeito ao casamento ou união estável, sejam desconsiderados diante de um equilíbrio na relação que permitiria a proteção integral e o direito à convivência familiar. Assim, todos os mecanismos jurídicos voltados para a tutela da criança e do adolescente devem se perpetuar por seus fins sociais e a possibilidade de amplo desenvolvimento, pois é através da família qual seja sua modalidade que o indivíduo nasce, cresce e se desenvolve, pois, a família Ihe presta assistência. Logo, respeitando a primazia do melhor interesse da criança e do adolescente. (FARIA e MAIA, 2019).

\section{Da sucessão}

A existência da pessoa natural termina com a morte real, como o complexo de relações jurídicas não pode ficar sem um detentor, temos o instituto da ficção jurídica que impõe a transmissão da herança, no mesmo instante em que ocorre a morte real. Assim, abre-se a sucessão, transmitindo automaticamente a herança aos herdeiros legítimos e testamentários, independente dos herdeiros ignorarem o fato, permitindo a continuidade na titularidade das relações jurídicas do defunto por meio da transferência imediata da propriedade aos herdeiros. Destarte, é concebido o direito sucessório, campo do direito privado que traz, em seu bojo, um conjunto de normas que dita a respeito da distribuição dos bens do de cujus a seus herdeiros, herança é um somatório em que se inclui os bens e as dívidas, os créditos e os débitos, os direitos e obrigações, as pretensões e ações de que era titular o falecido e as que contra ele foram propostas desde que transmissíveis. (DIAS, 2013)

A Equiparação se respalda no campo do direito das famílias, e por força do disposto no art. 1790 do Código Civil, que dispõe que um companheiro participará da sucessão do outro, sem exigência que haja relações biformes, logo, ainda que uniforme os companheiros integram a ordem de vocação hereditária, sendo exer- 
cida de forma legítima, veja (BRASIL, 2003): "A companheira ou o companheiro participará da sucessão do outro, quanto aos bens adquiridos onerosamente na vigência da união estável", portanto, ainda que não sejam casados, a decisão do Supremo Tribunal Federal impõe a equiparação entre companheiro e cônjuges, desde que o primeiro prove a união estável.

Nesse sentido, veja:

PROCESSUAL CIVIL. DIREITO CIVIL. UNIÃO ESTÁVEL HOMOAFETIVA. EQUIPARAÇÃO À UNIÃO ESTÁVEL HETEROAFETIVA. 1. Relações estáveis homoafetivas. Decisão que fez coisa julgada formal, reconhecendo a existência de "sociedade de fato" e não de "união estável". 2. Nessa hipótese, os reflexos patrimoniais são os mesmos do período anterior à legislação que estabeleceu a união estável no direito pátrio. 3. A partilha dos bens restringe-se àqueles que foram adquiridos pelo esforço comum, durante o período em que vigorou a sociedade. 4. Recurso especial conhecido e provido em parte. (STJ - REsp: 1284566 RS 2011/0232543-3, Relator: Ministro JOÃO OTÁVIO DE NORONHA, Data de Julgamento: 23/06/2015, T3 - TERCEIRA TURMA, Data de Publicação: DJe 26/06/2015).

A decisão é de repercussão geral e deve ser aplicada em todas as instâncias Judiciárias, o companheiro que comprova a união estável terá direito à meação da herança do falecido, sendo o restante dividido entre descendentes e ascendentes se houver. Não havendo, o cônjuge ou companheiro possui direito à integralidade do patrimônio.

Seria de má-fé e de enriquecimento ilícito, desvincular a união afetiva quando a seus efeitos sucessórios concedendo a herança a parentes distantes ao contrário de quem, em plena vida, desfrutou de uma união estável de dedicação plena ao parceiro, se afastarmos essa ideia estaremos diante de um resultado injusto a uma união que não pode ser negada e merece tutela jurídica efetiva pelo poder Judiciário e demais poderes, deve ser promovida mudanças legais ao grupos marginalizados e vilipendiados, como a opinião pública em relação a sexualidade é bastante divergente com fatores de discordância em relação a crenças religiosas e política, deve o legislador promover mudanças políticas e sociais que nem sempre seguem a opinião pública, mas que serve para modificá-la. 


\section{CONSIDERAÇÕES FINAIS}

O intuito do presente artigo foi abordar a temática LGBT sobre diversos ângulos desde a possibilidade de adoção por casais homossexuais a políticas públicas de educação. Inicialmente, analisando o sistema constitucional percebemos que as uniões homoafetivas foram elevadas implicitamente ao status de entidade familiar, já que a Constituição Federal visa proteger todas as famílias sob a égide do princípio da afetividade. Assim, considerando o valor protegido pelo art. 226 da Constituição Federal, aliado às técnicas de interpretação do Direito, como a analogia, reconhecemos o caráter familiar das uniões homoafetivas, pois possuem as mesmas características das uniões estáveis protegidas constitucionalmente (art. 226, $\S 3^{\circ}$ da Constituição Federal de 1988). Nessa esteira, devem ser atribuídos às uniões homoafetivas os mesmos direitos garantidos às uniões estáveis. Conferindo status de entidade familiar às uniões homoafetivas, verificamos também, que não há nenhum óbice aos homossexuais adotarem na legislação pertinente à adoção no Brasil, haja vista que a orientação sexual não é requisito para adoção. A Adoção como forma de colocação em família substituta deve atender ao princípio do melhor interesse da criança. A finalidade, portanto, da adoção é possibilitar ao menor seu direito à convivência familiar, garantindo o seu bem-estar, possibilitando seu pleno desenvolvimento.

Em conclusão, destaca-se a necessidade de combater a homofobia (e sexismo) no Brasil através do sistema educacional, e destaca-se uma série de obstáculos para a implementação das políticas brasileiras de sexualidade e educação para enfrentar a discriminação contra pessoas LGBT nas escolas. Além disso, aponta para a intersecção entre sexualidade e pobreza para essas pessoas que vivenciam a violência homofóbica.

\section{Referências}

BOBBIO, Noberto. A era dos direitos. Rio de Janeiro: Editora Campus, 1992.

BRASIL. Constituição (1988). Constituição da República Federativa do Brasil: promulgada em 5 de outubro de 1988. 
BRASIL. Lei n. 10.406, 10 de janeiro de 2002. Institui o Código Civil. Diário Oficial da União, Brasília, DF, 11 jan. 2002.

BRASIL. Superior Tribunal da Justiça - REsp: 1284566 RS 2011/0232543-3, Relator: Ministro JOÃO OTÁVIO DE NORONHA, Data de Julgamento: 23/06/2015, T3 - TERCEIRA TURMA, Data de Publicação: DJe 26/06/2015, Disponível em: https://stj.jusbrasil.com.br/jurisprudencia/524323837/recurso-especial-resp-1286632-rs-2011-0244419-4. Acesso em 16 de julho de 2020

DE SOUSA, L. M. R. O direito à assistência pós exposição: o portador do HIV, o Estado e o mercado de trabalho brasileiro. Conexão ComCiência, [S. I.], v. 1, n. 3, 2021. Disponível em: https://revistas.uece.br/index.php/conexaocomciencia/article/view/4938. Acesso em: 29 ago. 2021.

DIAS, Maria Berenice. Manual de direito das famílias. 9. ed. rev., atual. e ampl. São Paulo: Revista dos Tribunais, 2013.

DOVER, Kenneth James. A homossexualidade na Grécia Antiga. Trad. Luís Sérgio Krausz. São Paulo: Editora Nova Alexandria, 2007

FARIAS, Mariana de Oliveira; MAIA, Ana Cláudia Bortolozzi. Adoção por Homossexuais: A Família Homoparental Sob o Olhar da Psicologia Jurídica. Curitiba: Juruá, 2009.

GIDDENS, Anthony. O que é Sociologia? In: Sociologia. $4^{a}$ Ed, Porto Alegre: Artmed, 2016.

IRINEU, BA e Froemming, CN (2012) 'Homofobia, Sexismo e Educação: Notas Sobre as Possibilidades de Enfrentamento a Violência a Partir de um Projeto de Extensão Universitária ', Universidade do Estado do Rio de Janeiro: Revista Advir , julho: $75-90$

KANT, Immanuel. Fundamentação da metafísica dos costumes. São Paulo: Abril, 1980.

LOCKE, John. Segundo tratado sobre o governo civil. São Paulo: Abril Cultural, 1978. 
MELLO, L.; Brito, W. e Maroja, D. (2012) 'Políticas Públicas Para a População LGBT no.Brasil: Notas Sobre Alcances e Possibilidades ', Cadernos Pagu 39: 403-29

MELLO, L .; Freitas, F .; Pedrosa, CB e Brito, W. (2010) 'Para Além de um Kit Anti-homofobia: Políticas Públicas de Educação Para a População LGBT no Brasil ', Bagoas: Estudos Gays gêneros e sexualidades 7: 99-123

NOVELINO, Marcelo. Curso de direito constitucional. Salvador: JusPodivm, 2020.

ORGANIZAÇÃO INTERNACIONAL DO TRABALHO (2011) Igualdade no Trabalho: Um Desafio Contínuo, Relatório Global no quadro do seguimento da Declaração sobre os Princípios e Direitos fundamentais no Trabalho, Gabinete de Estratégia e Planeamento GEP / MTSS

PARKER, R. (2003) 'Aids in Brazil', in D. Herbert and R. Parker (eds), Sexuality, Politics and AIDS no Brasil: em outro mundo?, Londres: Falmer Press

ROUSSEAU, Jean-Jacques. Do contrato Social. São Paulo: Abril Cultural, 1985.

SILVA, D. D. B; CAEIRO, R. M. P. Homossexualidade e discurso: o espaço do sujeito "Gay" em revistas da década de 60 à contemporaneidade. In: SEMINÁRIO DE ESTUDOS DE ANÁLISE DO DISCURSO, 7., 2015, Recife. Anais... Recife, 2015. Disponível em: . Acesso em: 28 abr. 2021.

TERTO, A. P.; SOUZA, P. H. N. De Stonewall à Assembleia Geral da ONU: Reconhecendo os Direitos LGBT. Monções, Dourados, v.5, n.7,p. 120-148, jan/ jun. 2019 


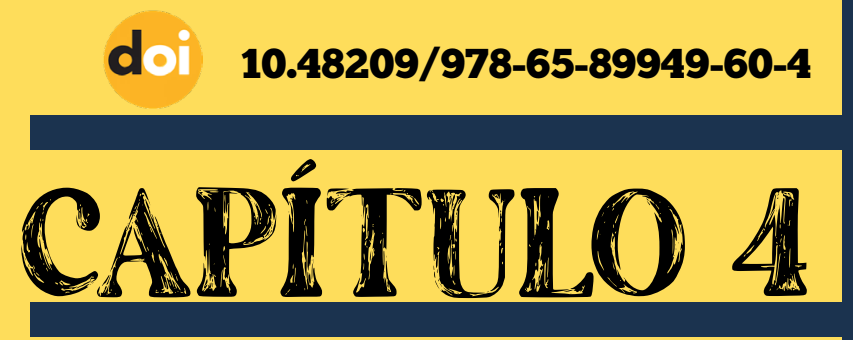

\section{A SOCIEDADE DA DESINFORMAÇÃO}

Lucas Melo Rodrigues de Sousa 


\section{INTRODUÇÃO}

Vemos o que queremos ou o que os algoritmos consideram melhor? Entendemos o alcance do uso de nossos dados pelas plataformas digitais? Os algoritmos filtram o conteúdo que consumimos de forma on-line diariamente priorizando, classificando, associando informações. Dessa forma, eles exercem o poder de moldar a experiência do usuário e até a percepção que temos do mundo.

Bem descreve Ferrari (2017):

Em primeiro lugar, nota-se a ampliação das formas de conexão entre indivíduos e, entre indivíduos e grupos. Esse aspecto proporciona a horizontalidade da comunicação e, portanto, a ruptura com o aspecto característico dos meios de comunicação tradicionais que se organizavam a partir da relação entre um emissor e muitos receptores. Nesse sentido, a internet proporciona, em primeiro lugar, a multiplicidade e heterogeneidade das conexões. Cada ponto da rede pode realizar conexões infinitas com múltiplos pontos descentralizados, um rizoma geolocalizável de ocupação de espaços, que estão em constante movimento, pois vivemos um presente "tagueado", ou seja, um tempo que pode ser resgatado a qualquer minuto por bancos de dados, mas que não se torna desejado, pois a presentificação se impõe sobre a memória. Como o vivenciar é líquido e, no minuto seguinte, estamos vivenciando outra postagem, o tempo necessário para o cérebro verificar a veracidade do fato narrado fica prejudicado, pois na maioria das vezes, só para citar um exemplo, os consumidores compartilham a informação apenas pelo título, sem dar o trabalho de ler o texto completo ou mesmo verificar a fonte de informação.

Os aplicativos e plataformas que usamos todos os dias usam Inteligência Artificial (IA) para tomar decisões com base na enorme quantidade de dados precisos que eles obtêm de nossas contas e das informações presentes em nossos perfis. A partir do processamento desses dados por meio da IA, eles estruturam os gostos e preferências dos usuários e monetizam essas informações, entre outras coisas, contribuindo para a Microtargeting que os anunciantes implementam para alcançar usuários específicos.

Tendo em conta este cenário, podemos concluir que poucas pessoas são informadas sobre como os algoritmos moldam o espaço digital que as cerca e suas implicações nas decisões que tomamos. 
Por esse motivo, é tão importante aumentar a conscientização e capacitar as pessoas, para que elas adquiram as ferramentas necessárias para assumir o controle de suas experiências nas plataformas que usam. Como cidadãos digitais em formação, merecemos estar cientes e entender o poder que os algoritmos têm sobre nós.

À vista que o acesso à internet é realidade para milhares de pessoas no Brasil e no mundo. No Brasil (Pnad Contínua TIC, 2020), três entre quatro cidadãos possuem acesso à internet e, segundo estudos da Organização das Nações Unidas - ONU (2020), mais de 50\% da população mundial encontra-se conectada.

\section{NEWS FEED}

News feed é a página do Facebook que expõe ao usuário suas próprias postagens e postagens de terceiros. Segundo o Facebook, as postagens perpetuadas ao News Feed são influência das relações do usuário a outros indivíduos e por suas próprias postagens (likes, comentários, etc.). Dessa forma "O algoritmo do feed de notícias veicula o que 'pensa' ser a sua opinião e a de seus amigos e certamente não checa fatos" (CELLAN-JONES, 2016, documento online)

Entretanto, nem tudo que é postado será exposto no News Feed de todos os usuários, sendo empregados sistemas computacionais para filtrar o conteúdo exposto, impedindo sobrecarga de informações e sujeitando, em tese, o que é interesse aos usufrutuários.

Nesse sentido:

O que um mecanismo como o Feed de Notícias faz ao definir o que é relevante para cada um de seus usuários não é algo estabelecido apenas pela sua capacidade técnica em realizar essa função. Isto é, parte-se do entendimento que o que os mecanismos fazem e seus usos esperados são noções definidas em processos relacionais, de negociação, que tem como parte importante a percepção dos usuários sobre o que cada funcionalidade representa e para que serve. (AKRICH; LATOUR, 1992) 
Quando foi postado: quanto mais recentemente uma história foi postada, maior a probabilidade de você vê-la. No entanto, o Facebook também detecta quando você verificou o NewsFeed pela última vez e classifica as postagens boas e mais antigas em uma posição superior se você não tiver feito login desde que foram postadas e não as tiver visto. Verifique a cada poucos minutos ou horas e o Facebook priorizará as postagens mais recentes. Fique off-line por uma semana e o Facebook pode trazer à tona uma grande história, como seu melhor amigo ter um bebê, mesmo que tenha sido postada há 5 dias.

Hoje em dia o Facebook utiliza um sistema de algoritmo de aprendizagem de máquina (um sistema de dados em busca de padrões) para filtrar a seleção de posts exibidos no News Feed do usufrutuário. Diferente do EdgeRank, esse algoritmo é modificado frequentemente e leva em consideração, atualmente, 100.000 fatores. A discussão surge pela filtragem de dados realizada pelos algoritmos.

\section{O LADO OBSCURO DOS ALGORITMOS}

Como apresentado, o Facebook utiliza códigos computacionais para eleger aquilo que seus usuários auferiram em seus News Feed. Todavia, esses algoritmos são proprietários, ou seja, apenas seus criadores compreendem como verdadeiramente funcionam. Não há como ter ciência de como e quais dados serão de fato expostas aos usuários, o que nos leva a algumas ocorrências de interesse jurídico, veja:

Vícios de qualidade do serviço: se o funcionamento dos algoritmos de filtragem dos dados não é de conhecimento dos usuários, potencialmente pode proceder em condutas não esperadas, aplicando-se, nesses casos, o exposto no parágrafo $2^{\circ}$ do CDC (Código de Defesa do Consumidor): "São impróprios os serviços que se mostrem inadequados para os fins que razoavelmente deles se esperam, bem como aqueles que não atendam as normas regulamentares de prestabilidade".

Concorrência desleal: os algoritmos são capazes de privilegiar algumas marcas e produtos em prejuízo dos outros, lesando o princípio da livre concor- 
rência e ocasionando abuso de direito, desvio de clientela, entre outros. Dessa forma grandes marcas acabam engolindo pequenos negócios em virtude da disponibilidade financeira para investir em marketing e links patrocinados.

Muitas vezes empresas menores quando possuem acesso a tal mecanismo acabam por utilizar-se de similitude com grandes marcas, potencializando confusão no público consumidor, com enquadramento no disposto no artigo 195, inciso III da Lei 9.278/2006.

Esse foi o entendimento da $1^{\text {a }}$ Câmara de Direito Empresarial do Tribunal de Justiça de São Paulo ao condenar uma marca de colchões por ter vinculado seu próprio site à expressão "pillowmed", registrada no Instituto Nacional de Propriedade Industrial (INPI) por uma concorrente, que é a autora da ação.

Ao associar sua marca à expressão de uma concorrente, a empresa ré cometeu concorrência desleal, decorrente de violação da marca, segundo o relator, desembargador Fortes Barbosa. O Google também foi condenado por ter colaborado para o desvio de clientela da autora da ação.

Para o desembargador, a sobreposição da apresentação de um produto ou serviço fornecido por empresa menos conhecida configura "aproveitamento parasitário da fama alheia, o que implica na violação das regras de conduta impostas para a salvaguarda da convivência entre os empresários": "Restará caracterizada a concorrência parasitária sempre quando persistir a exploração indevida do prestígio alheio para promoção de produtos ou serviços".

A empresa ré deve se abster de usar a expressão "pillowmed" como palavra-chave no Google, por meio da ferramenta "AdWords". O TJSP também majorou a indenização por danos morais à autora, que passou de $\mathrm{R} \$ 5$ para $\mathrm{R} \$ 30$ mil. "Há elementos suficientes para reconhecer que a utilização indevida da marca de titularidade da autora provocou uma degradação, ainda que localizada, na propriedade industrial", concluiu Fortes Barbosa.

Comando da vida digital: exibindo apenas informações filtradas pelos sistemas proprietários, a mesma cria, com potência, bolhas de dados que enclau- 
suram seus usuários, ocorrendo manipulação não aprovada de opiniões, pois o filtro de dados pode induzir à distorção de fatos e alterar resultados nos mais diversos âmbitos, como por exemplo nas últimas eleições presidenciais brasileiras,' 'De percepções pessoais sobre os usos das plataformas digitais até a cobertura jornalística sobre eleições preside percepções pessoais sobre os usos das plataformas digitais até a cobertura jornalística sobre eleições presidenciais, algoritmos têm ocupado a posição de sujeito nesses enunciados". (ZIEWITZ, 2015)

Fake news consistem na divulgação na disseminação descontrolada de desinformações ou boatos. Este tipo de notícia é escrita e publicada com o intuito proposital de enganar ou ludibriar. Essa prática embora reprovável é utilizada com frequência atualmente, objetivando influenciar a opinião pública, sobre os mais diversos assuntos, sendo a internet o veículo mais utilizado. " O conceito fake news tornou-se componente importante nas lutas políticas contemporâneas e passou a ser utilizado por diferentes posições dentro do espaço social como meio de desacreditar, atar e deslegitimar adversários políticos." (FARKAS; SCHOY, 2016, online).

Um relatório oficial do Facebook redigido por Weedon, Nuland e Stamos define assim as notícias falsas:

O termo "notícias falsas" emergiu como uma expressão abrangente para se referir a todo tipo de coisa desde artigos de notícias que são factualmente incorretos até artigos de opinião, paródias e sarcasmo, boatos, rumores, memes, abuso online e erros factuais em declarações de figuras públicas que são corretamente mencionadas em matérias noticiosas (...) Artigos de notícias que parecem ser factuais mas que contêm distorções intencionais de fatos com o propósito de provocar paixões, atrair audiência ou enganar. (FACEBOOK SECURITY, 2017, p.4)

O termo evoluiu cada vez mais para se tornar o que o filósofo Ernesto Laclau (2005) define como floating signifier, isto é, "um significante usado por projetos políticos fundamentalmente diferentes e, em muitos aspectos profundamente opostos, como um meio de construir identidades políticas, conflitos e antagonismos". 
Cada vez mais as pessoas estão submetidas às decisões automáticas dos algoritmos, sem que saibam de que forma foi feita a escolha, ou seleção. Como argumenta O'Neil (2016) a falta de transparência sobre seu funcionamento indica a tendência de que estes mecanismos segregam determinadas informações, privilegiando outras, reproduzindo padrões de preconceito e discriminação de gênero, de raça e de renda, dentre outras, reforçando assim o aprofundamento das desigualdades da sociedade.

Delmazo e Valente (2018) transcrevem:

Há ainda uma distância entre a partilha dos links e a sua leitura em si. Estudo divulgado em junho de 2016 pela Universidade de Columbia e o Instituto Nacional Francês mostra que 59\% dos links partilhados em redes sociais não chegam a ser clicados de facto (DEWEY, 2016). Dessa forma, uma manchete atraente - que normalmente fica explícita na URL do link - já seria suficiente para garantir engajamento. Mesmo quando os links são clicados, poucos leitores vão passar dos primeiros parágrafos, o que facilita ainda mais o trabalho de elaboração de uma notícia falsa. Estudo do Nielsen Norman Group divulgado em 2013 mostrou que 81\% dos leitores voltam os olhos - o que não significa necessariamente que estão, de fato, a ler - para o primeiro parágrafo de um texto na internet, enquanto $71 \%$ chegam ao segundo. São $63 \%$ os que olham para o terceiro parágrafo, e apenas $32 \%$ voltam os olhos para o quarto. (NIELSEN, 2013). O estudo foi feito com base no eye-tracking, conjunto de tecnologias que regista os movimentos oculares de um indivíduo determinando em que áreas fixa a sua atenção, por quanto tempo e que ordem segue na sua exploração visual (BARRETO, 2012). Outro desafio ainda se coloca na qualidade da leitura.

Utilização indevida de dados pessoais e economia dos algoritmos: os algoritmos de seleção de postagem coletam informações e comportamentos dos usuários, informações que podem ser utilizadas para fins não devidamente claros, como fornecimento e venda a terceiros.

Com relação específica da internet pode-se destacar a contribuição formulada por Danilo Doneda, segundo a qual com o constante avanço tecnológico chegou-se a uma evolução, que se refletia na insatisfação dos cidadãos que sofriam com a utilização de seus dados por terceiros, e diante disso careciam de mecanismos para tutelar tais interesses. Assim sendo, surgiram alguns princípios, resumidos por Doneda, tais como: 
Princípio da publicidade (ou da transparência), pelo qual a existência de um banco com dados pessoais deve ser de conhecimento público, seja por meio da exigência de autorização prévia para funcionar, da notificação a uma autoridade sobre sua existência, ou do envio de relatórios periódicos; Princípio da exatidão: os dados armazenados devem ser fiéis à realidade, o que compreende a necessidade de que sua coleta e seu tratamento sejam feitos com cuidado e correção, e de que sejam realizadas atualizações periódicas conforme a necessidade;Princípio da finalidade, pelo qual qualquer utilização dos dados pessoais deve obedecer à finalidade comunicada ao interessado antes da coleta de seus dados. Este princípio possui grande relevância prática: com base nele fundamenta-se a restrição da transferência de dados pessoais a terceiros, além do que se pode, a partir dele, estruturar-se um critério para valorar a razoabilidade da utilização de determinados dados para certa finalidade (fora da qual haveria abusividade); Princípio do livre acesso, pelo qual o indivíduo tem acesso ao banco de dados no qual suas informações estão armazenadas, podendo obter cópias desses registros, com a consequente possibilidade de controle desses dados; após este acesso e de acordo com o princípio da exatidão, as informações incorretas poderão ser corrigidas e aquelas obsoletas ou impertinentes poderão ser suprimidas, ou mesmo pode-se proceder a eventuais acréscimos; Princípio da segurança física e lógica, pelo qual os dados devem ser protegidos contra os riscos de seu extravio, destruição, modificação, transmissão ou acesso não autorizado.

Em relação à privacidade, seu aspecto mais destacado atualmente é o controle da circulação das informações pessoais. Nesse sentido, afirmou-se que a configuração atual da privacidade teria ultrapassado o eixo "pessoa-informação-segredo" para se estruturar na "pessoa-informação-circulação-controle". A liberdade de expressão, considerada como liberdade de externar ideais, juízos de valor e as mais variadas manifestações do pensamento, além de já ser amplamente protegida pelo constituinte, apresenta no $\mathrm{MCl}$ tutela destacada, sendo considerada um fundamento e um princípio para a disciplina do uso da internet no Brasil e condição para o pleno exercício do direito de acesso. Ao longo do Marco Civil, percebe-se a preocupação do legislador com a compatibilização desses princípios, tendo por fim assegurar que, também na internet, a pessoa humana possa livremente desenvolver sua personalidade.

O perigo do roubo de dados: se seus dados forem roubados, você poderá enfrentar um influxo de ataques de spam. Talvez haja alguns telefonemas de números estranhos em países que você não conhece ninguém. Eles tocam e 
desligam antes que você tenha a chance de atender, porque o objetivo deles é tentar fazer com que você ligue de volta e acumule tarifas de longa distância que iriam para eles. Ou talvez seu e-mail tenha sido roubado e um ataque de phishing cuidadosamente elaborado (usando seus dados pessoais contra você).

O perigo do dinheiro ser roubado: existem duas maneiras principais de roubar dinheiro por meio de um hack online. Um, que as informações pessoais roubadas são suficientes para acessar sua conta bancária. Dois, os detalhes do seu cartão de crédito foram roubados

Algoritmos e software por si só não são suficientes para proteção, e é por isso que se recomenda:

Uso de senhas exclusivas e complicadas para contas importantes.

Exclusão de contas antigas.

Monitoramento de fraudes de phishing e malware

Backup de informações importantes offline

Software atualizado frequentemente.

Instalação de software antivírus.

Adaptado de Francisco (2004)

Não há garantia de que você nunca enfrentará um ataque, porém, saber o que procurar e como minimizar a propagação da infecção pode ajudá-lo a voltar ao caminho certo

Francisco (2004) interpreta a sociedade da desinformação da seguinte maneira:

Por mais que esteja armada por um poderoso arsenal de tecnologias de informação, uma sociedade que produz uma legião de analfabetos funcionais é uma sociedade da desinformação. Para que cumprissem as predições dos profetas da era virtual, as tecnologias da informação precisam agregar valores éticos, educacionais, sociais, humanistas, culturais, artísticos e espirituais. 


\section{CONSIDERAÇÕES FINAIS}

Ante o exposto, é instintivo deduzir que os sistemas computacionais de seleção de dados frequentemente trabalham em desfavor à sociedade. Termos noção de que existem e como funcionam é extremamente necessário, apontando uma devida alfabetização virtual. Necessário é que haja legislação específica quanto à transparência da utilização de dados, tendo em vista que estes são capazes de alterar o destino de diversas áreas.

Os direitos humanos e fundamentais quando vinculados ao âmbito virtual buscam estabelecer um status de democracia na internet, em que haja transparência, visibilidade e capacidade de representação do povo. A internet é agnóstica e pode ser utilizada para o bem ou mal, ainda que inicialmente possua a proposta de levantar participação cidadã e ampla pesquisa. Prova disso é que tem se observado grande utilização dessa ferramenta de modo que ocorra lesão a direitos humanos.

No mundo online, é basilar materializar o Marco Civil da Internet e seu artigo 19 como instrumento que está a serviço da efetivação dos direitos humanos, com inclusão da liberdade de expressão. Vale enfatizar, para não restar qualquer dúvida, que a liberdade de expressão não é e nem pode ser fundamento para a violação de outros direitos humanos.

Medidas educativas acionadas por meio de políticas públicas demandadas para combater violações de direitos na internet também são fundamentais. Criar mecanismos que coajam os provedores de aplicação e conteúdo a darem maior transparência às suas políticas e termos de uso, criar efetivamente instrumentos de intermediação entre esses provedores e seus usuários e tornar mais claros os critérios para promoção de postagens, descerramento de publicidade e de funcionamento de seus algoritmos, que incitam a bolha do preconceito e do ódio.

Face a isso, a democracia que construímos deve ser levada de modo mais ativo para o ambiente virtual, sendo necessário que todos entendam como a internet deve funcionar. Isso pode ser implementado por meio de uma alfabeti- 
zação digital coletiva, partindo da ideia de que todo ser humano possui direito à instrução em graus elementares e fundamentais. Assim sendo, ainda é necessário que o acesso à internet faça parte da rotina de toda a população mundial, pois é onde pode haver o exercício do direito à liberdade de opinião sem fronteiras, bem como deve-se promover a igualdade e verdadeiro exercício da dignidade da pessoa humana também nesse ambiente.

\section{REFERÊNCIAS}

Agência Brasil. Um em cada quatro brasileiros não têm acesso à internet. Disponível em: https://agenciabrasil.ebc.com.br/economia/noticia/2020-04/um-em-cada-quatro-brasileiros-nao-tem-acesso-internet. Acesso em: 21 agosto de 2020

AKRICH, M. The De-scription of Technical Objects. In: BIJKER, W. E.; LAW, J. (Org.). Shaping Technology / Building Society: Studies in Sociotechnical Change. Cambridge: The MIT Press, 1992, p. 205-22

BARRETO, Ana Margarida. Eye tracking como método de investigação aplicado às ciências da comunicação. Revista Comunicando, v.1, n.1, Dez. 2012,168186. Disponível em: http://www.revistacomunicando.sopcom.pt/ficheiros/ 20130108-tracking.pdf. Acesso: 17 out. 2018.

BRASIL. Organização das Nações Unidas. Internet e direitos humanos. Disponível em: https://nacoesunidas.org/artigo-internet-direitos-humanos/. Acesso em: 21 agosto de 2020.

CARSON, James. Fake News origens grew, TELEGRAPH, 2016. Disponível em :http://www.telegraph.co.uk/technology/0/fake-news-origins-grew-2016/. Acesso em 18 de setembro de 2020.

DELMAZO, Caroline; VALENTE, Jonas C. L. Fake news nas redes sociais online: propagação e reações à desinformação em busca de cliques. Media \& Jornalismo, [S.I.], v.18, n. 32, p. 155-169, maio de 2021. Disponível em: <http://impactumjournals.uc.pt/mj/article/view/5682>. Acesso em: 07 ago de 2021

DEWEY, C. (2016). 6 in 10 of you will share this link without reading it, a new, depressing study says. 16/06/2016. The Washington Post. Retrieved from https:// www.washingtonpost.com/news/the-intersect/wp/2016/06/16/six-in-10-of-you-will-share-this-link-withoutreading-it-according-to-a-new-and-depressing-study/.. 
DONEDA, Danilo. (1). A proteção dos dados pessoais como um direito fundamental. Espaço Jurídico Journal Of Law [EJJL], 12(2), 91-108. Disponível em: . Acesso em: 30 de fev. 2021

CELLAN-JONES, R. Como o Facebook pode ter ajudado Trump a ganhar a eleição. Folha de São Paulo, [S.I.], 2016. Disponível em: <http://www1.folha.uol.com.br/ mundo/2016/11/1831829-como-o-facebook-pode-ter-ajudado-trump-a-ganhar-a-eleicao.shtml>. Acesso em: 31 de fevereiro de 2021.

FARKAS, Johan; SCHOU, Jannick. Fake News as a Floating Signifier - The Public Journal of the European Institute for Communication and Culture, 2018.

FERRARI, Pollyana. Fake news, pós-verdade e o consumo de informações. In: XXVI ENCONTRO ANUAL DA COMPÓS, 26., 2017, São Paulo. Anais... São Paulo: Faculdade Cásper Líbero; 2017. Disponível em: Acesso em: 30 jul. 2021.

FRANCISCO, Severino. Sociedade da desinformação. Artigo publicado no Observatório da Sociedade da Informação, de responsabilidade do Setor de Comunicação e Informação da UNESCO no Brasil. Brasília, 2004. Disponível em: Acesso em: 15 jul. 2021.

LACKAU, E. The Populist Reason, London, 2005.

LATOUR, B. The pasteurization of France. Cambridge: Harvard University Press, 1993.

NIELSEN, J. (2013). Website Reading: It (Sometimes) Does Happen. Disponível em: https://www.nngroup.com/articles/website-reading/. Acesso: 17 out. 2018

O'NEIL, Cathy. Weapons of math destruction: How big data increases inequality and threatens democracy. Broadway Books, 2016.

ZIEWITZ, M. Governing algorithms: myth, mess, and methods. Science, Technology \& Human Values, v. 41, n. 1, p. 3-16, 2015. 


\section{dol $10.48209 / 978-65-89949-60-5$}

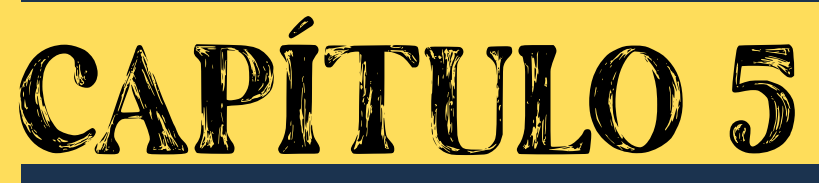

\section{MEIO AMBIENTE ECOLOGICAMENTE EQUILIBRADO: DO DIREITO, DA MANUTENÇÃO E DAS TESES DOS}

TRIBUNAIS SUPERIORES

Raphael Teixeira do Vale Lucas Melo Rodrigues de Sousa 


\section{INTRODUÇÃ}

O direito ao meio ambiente ecologicamente equilibrado vai além da esfera do indivíduo, ultrapassa o interesse coletivo e projeta-se como um direito intergeracional: determina responsabilidades desta geração com as gerações futuras, e assim em constante sequência. É um direito e dever pertencente a todos os indivíduos que habitam o globo terrestre, pois é consubstanciado no dever de proteção e defesa para que haja sustentabilidade ambiental. O presente estudo objetiva tecer breves considerações acerca do direito ao meio ambiente ecologicamente equilibrado, verificando medidas de mitigação em decorrência de sua lesão e por fim apresentar as atuais teses dos Tribunais Superiores.

\section{O DIREITO AO MEIO AMBIENTE EQUILIBRADO}

Equilíbrio ecológico é um termo usado para descrever organismos vivos como seres humanos, plantas, animais bem como seu meio ambiente. A fotossíntese que ocorre no ecossistema contribui para a construção de um bom ambiente que estabiliza a coexistência de todos os organismos, relacionamentos harmoniosos refletem um equilíbrio ecológico saudável e desejável.

O ser humano desempenha um papel fundamental para manter o equilíbrio ecológico porque tem a maior capacidade de pensamento em comparação com outros organismos vivos. A disponibilidade suficiente de alimentos para todos os organismos vivos e sua estabilidade refletem a existência de equilíbrio ecológico, a sobrevivência de todos os organismos é realizada devido ao equilíbrio ecológico, várias espécies sobrevivem porque ecossistemas favoráveis foram criados, assim garante-se que cada organismo prospere e se multiplique conforme o esperado, pois eles recebem comida suficiente para mantê-los vivos.

O equilíbrio ecológico também é importante porque leva à existência contínua dos organismos, ele garante que nenhuma espécie em particular seja explorada ou usada em demasia por exemplo as atividades humanas como a agricultura e a exploração de recursos são controladas para evitar a destruição 
excessiva das florestas, pois o desmatamento leva à seca, a seca reduz a produção de alimentos, resultando em alimentos insuficiente, alimentos insuficientes levam à fome e morte posterior, reduzindo assim a existência de algumas espécies.

Além disso, o equilíbrio ecológico garante a estabilidade dos organismos e do meio ambiente. Ele cria um ambiente propício para a multiplicação e prosperidade de organismos, melhorar um ambiente instável e com desequilíbrios ecológicos: enchentes, fome causada pela seca, vendaval que pode varrer tudo e a caça de predadores exigem esforços coletivos.

O plantio de árvores e a redução da taxa de desmatamento evitam mudanças climáticas indesejáveis, o controle de habitantes excessivos de animais selvagens mantém o crescimento populacional desejado, portanto, um ser humano pode contribuir positivamente para criar e manter o equilíbrio ecológico.

\section{MANEIRAS DE SE MANTER O MEIO AMBIENTE EQUILIBRADO}

Os organismos da Terra interagem com o meio ambiente em um ciclo delicadamente equilibrado, as plantas usam a energia do sol e se tornam alimento para outras criaturas. $\mathrm{O}$ ciclo continua à medida que as formas de vida vegetal $\mathrm{e}$ animal morrem e são consumidas por microorganismos, porém, este ciclo de vida está em risco pelo uso excessivo dos recursos naturais pela humanidade e pelos danos ao ecossistema causados pela poluição.

A expansão da civilização inflige um fardo crescente ao ecossistema. Minerais, combustíveis fósseis e outros recursos naturais desaparecem em um ritmo alarmante. A sobrepesca e a destruição do habitat criam uma perda de biodiversidade que terá consequências negativas de longo prazo para o ecossistema. O uso excessivo ou a destruição de seus habitats ameaçam as espécies de extinção.Isso pode ser visto em ecossistemas marinhos, onde a perda de apenas algumas espécies pode ameaçar um ecossistema inteiro. Um esforço concentra- 
do para usar os recursos naturais de maneira sustentável ajudará a proteger e manter o equilíbrio ecológico.

Na natureza, os predadores impedem as espécies de superpopulação, infelizmente, os humanos não têm predadores naturais para controlar a população, é necessário agir em nível individual e governamental para controlar a população. Este problema é importante apesar da sensibilidade emocional, cultural ou religiosa ao assunto. Assim como muitos peixes em seu aquário sujam a água, muitos humanos no planeta podem perturbar o equilíbrio ecológico.

Entre 1927 e 1987, a população da Terra aumentou para 5 bilhões. No ano de 1999, a população total atingiu 6 bilhões, e estima-se que quase 9 bilhões de pessoas viverão na Terra no ano de 2050. O controle da taxa de natalidade por meio da contracepção e do planejamento familiar reduzirá a pressão sobre o ecossistema, reduzindo a taxa em que as pessoas consomem recursos naturais. (ANTUNES, 2014)

A contaminação de esgoto e a poluição de manufatura e escoamento agrícola ameaçam o equilíbrio dos ecossistemas marinhos. O esgoto e o escoamento agrícola podem causar uma cascata de efeitos prejudiciais ao ecossistema. Tomar medidas para reduzir ou eliminar a poluição de fontes difusas, como ruas e fazendas, ajudará a manter o equilíbrio ecológico.

O esgoto e o escoamento de fertilizantes agrícolas podem causar o rápido crescimento de algas em lagos e riachos. O crescimento de algas bloqueia a luz do sol e esgota o oxigênio da água, isso causa uma redução na quantidade de vida vegetal natural no ecossistema marinho. Os animais que se alimentam das plantas morrem, o que leva à morte dos animais que os atacam. As algas em decomposição promovem o crescimento de organismos anaeróbicos, que liberam compostos tóxicos para os animais marinhos na água. Economize energia e escolha aparelhos e automóveis com maior eficiência energética. Se todos usarem menos energia, a poluição diminui e menos carvão será usado para abastecer a nação e o mundo.. (ANTUNES, 2014) 


\section{LEGISLAÇÃO AMBIENTAL}

Não obstante os muitos aspectos positivos da legislação ambiental do país, a redação das leis ambientais é frequentemente confusa e vaga e, portanto, vastas controvérsias sobre sua interpretação são comuns. Além disso, as discussões sobre as regras ambientais prevalecerem sobre os interesses privados é um tema igualmente debatido.

Nesse cenário, os tribunais brasileiros têm sido constantemente desafiados com a tarefa de dar a devida interpretação aos mandamentos normativos, que necessariamente devem ser cumpridos em consonância com seu dever constitucional de salvaguarda do meio ambiente.

Devido ao amplo leque de disciplinas que estão vinculadas às questões ambientais, esse processo tem exigido dos juízes um certo nível de especialização em outras áreas que não o direito e um certo grau de sensibilidade ecológica.

Os juízes têm certamente uma séria responsabilidade "[...] para enfatizar o significado ecológico do desenvolvimento sustentável, em particular no processo de integração de interesses diversos, e muitas vezes em conflito" (VOIGT, 2013, p. 38). Isso requer grandes esforços e um movimento contínuo de aprimoramento de suas técnicas de interpretação e análise de casos.

Neste sentido, o Supremo Tribunal de Justiça tem vindo a demonstrar na sua jurisprudência de cujas decisões emblemáticas serão abordadas posteriormente exemplos exitosos de adoção de orientações e princípios do Estado de Direito e da hermenêutica ambiental. As decisões têm frequentemente fornecido soluções interessantes e constitucionalmente adequadas para as complexas controvérsias decorrentes da crise ecológica antropocêntrica.

No que se refere à aplicação da hermenêutica ambiental pelo judiciário, em geral esta deve ser norteada pelos princípios explícitos e implícitos estabelecidos pelo texto constitucional (MORATO LEITE; VENÂNCIO, 2015), reconhecendo inicialmente uma maior relevância para o meio ambiente quando se verifica uma 
colisão de interesses, portanto, consiste em uma abordagem multidisciplinar, que engloba temas como epistemologia ambiental, justiça e ética adotando uma perspectiva sistêmica e teleológica para a análise de casos de direito ambiental (MORATO LEITE; VENÂNCIO, 2015)

JOSÉ LEITE E GERMANA BELCHIOR (2009) defendem assim que nos casos em que o direito fundamental ao meio ambiente colide com outros direitos fundamentais duas etapas devem ser seguidas pelo Judiciário, a saber, a avaliação de todos os interesses, valores e bens públicos e privados envolvidos na colisão e posterior aplicação do princípio da proporcionalidade, conferindo a princípio um peso maior ao meio ambiente.

Além disso, HERMAN BENJAMIN (2014) propõe que a aplicação da hermenêutica ambiental deve ser orientada principalmente por alguns temas específicos, em particular: (1) o princípio da não regressão, (2) o dever do Estado de restaurar os processos ecológicos essenciais, que inclui o dever de preservar o que existe e o dever de restaurar o que foi danificado; (3) dever do Estado de preservar a biodiversidade e os recursos genéticos; (4) o princípio da função ecológica da propriedade; e (5) o princípio in dubio pro natura .

Segundo este último, em caso de incerteza, as questões devem ser resolvidas de forma a favorecer a proteção e conservação do meio ambiente, dando-se preferência a alternativas menos nocivas ao meio ambiente. Este princípio implica na prevenção da realização de ações quando seus potenciais impactos adversos ao meio ambiente são desproporcionais ou excessivos em relação aos benefícios deles derivados.

Em suma, nos últimos anos o STJ vem aplicando os princípios e estratégias da hermenêutica ambiental a diversas controvérsias criminais, administrativas e civis relacionadas ao meio ambiente, apresentando resultados positivos. $O$ Tribunal tem contribuído para que o Estado cumpra com o seu dever de proteção do ambiente ao mesmo tempo que contribui para a aplicação da lei, constituindo uma sólida jurisprudência para os tribunais de primeira instância e os juízes locais. 
Isso mostra que os juízes dos Tribunais estão cada vez mais compreendendo e lidando adequadamente com a complexidade das questões ambientais transdisciplinares. O pensamento complexo implica o abandono do raciocínio linear, típico do paradigma modernista, e a compreensão do mundo sob uma perspectiva global não uniforme.

Diante desse cenário, dedicamos a próxima seção às principais decisões recentes do STJ em matéria ambiental, destacando situações emblemáticas em que os princípios do direito ambiental foram devidamente convocados e utilizados em consonância com um estado de direito para a natureza.

\section{JURISPRUDÊNCIA DOS TRIBUNAIS SUPERIORES: DESENVOLVI- MENTOS RECENTES E OPERACIONALIZAÇÃO DE PRINCÍPIOS}

O STJ é o tribunal de mais alta instância no Brasil para a legislação federal, portanto, tem a importante atribuição de uniformizar a interpretação das leis federais no sistema judiciário do país. A jurisprudência do STJ orienta os Tribunais Estaduais e os juízes locais, que devem proferir decisões em linha com a jurisprudência do Tribunal Superior.

Disputas sobre responsabilidade civil e compensação de danos ambientais; áreas protegidas e seus aspectos legais; crimes ambientais; e as limitações à autoridade dos órgãos do Estado são apenas alguns dos assuntos sobre os quais o Tribunal tem proferido decisões.

Embora a jurisprudência do STJ em relação às questões ambientais seja vasta e diversa, muitos dos entendimentos e opiniões mais relevantes da jurisprudência do Tribunal podem ser verificados em suas Teses de Direito Ambiental.

A Série de Teses do STJ é uma publicação periódica elaborada pela Secretaria de Jurisprudência do Tribunal e que reúne os principais desdobramentos da jurisprudência do Tribunal, com cada edição focando em um tema jurídico específico. Sintetizadas por HERMAN BENJAMIN (2014), Veja algumas: 
$1^{\text {a }}$ Tese: A condenação simultânea e cumulativa das obrigações de fazer, não fazer e para compensar é admitido dentro da aplicação do princípio da compensação completa por danos ambientais;

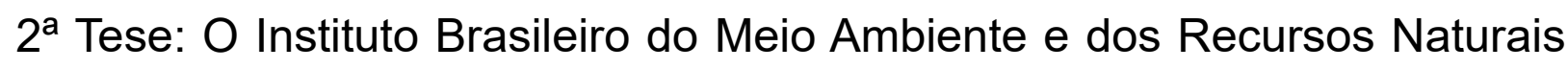
Renováveis (IBAMA) não pode impor sanções administrativas além das expressamente previstas em lei;

$3^{a}$ Tese: Não há direito adquirido a poluir ou degradar o meio ambiente e a legislação brasileira não permite que um proprietário de terras continue com as práticas em curso proibidas por lei, por exempl o titular de uma licença ambiental pode ter seu direito revogado ou modificado se as condições sob as quais a licença foi concedida mudarem significativamente e a atividade ou propriedade licenciada começar a prejudicar o meio ambiente;

$4^{\text {a }}$ Tese: O princípio da precaução requer a inversão do ónus de prova da prova; portanto, a pessoa que supostamente causou o dano ambiental deverá provar que não foi responsável por isso ou que a substância lançada no meio ambiente não é suscetível de prejudicá-lo;

$5^{\mathrm{a}}$ Tese: O IBAMA não pode impor sanções por infracções penais que são da jurisdição Tribunais;

6 a Tese: O uso do fogo em práticas agropastoris e florestais requer autorização prévia emitida pelo Estado;

$7^{\text {a }}$ Tese: Os responsáveis pela degradação ambiental são solidariamente responsáveis, a lei determina, como regra o litisconsórcio de partidos em classe ou ações coletivas;

$8^{a}$ Tese: No que diz respeito à proteção ambiental, o Estado é civilmente responsável quando a sua omissão no exercício do seu dever de supervisão quando representam uma circunstância relevante para a ocorrência ou agravamento do dano ambiental; 
9a Tese: O proprietário de um imóvel tem a obrigação de corrigir qualquer degradação ambiental ou danos infligidos sobre ele, mesmo se ele ou ela não deu causa que, dada a propter rem natureza dos danos ambientais;

10 ${ }^{a}$ Tese: A responsabilidade por danos ambientais é rigorosa, de acordo com a teoria do risco integral, portanto, uma empresa responsável pelo dano ambiental não pode discutir razões para exclusão de responsabilidade civil em sua defesa;

$11^{a}$ Tese: A Administração Pública tem cinco anos para aplicar a multa relacionada com infrações ambientais, a ser contado a partir do fim do processo administrativo.

É importante lembrar que as Teses Ambientais do STJ são fruto de decisões reiteradas sobre a mesma matéria, onde se aplicou raciocínio semelhante. Além disso, representam uma adoção de posições de vanguarda por parte do tribunal, que muitas vezes vem emitindo decisões alinhadas com a ideia de alcançar uma proteção ambiental integral, salvaguardando o interesse público em detrimento do privado (por exemplo, décima tese).

De certa forma, essas decisões atendem ao desafio de alcançar um sistema mais verde em nível judicial, pois operacionalizam nossa estrutura constitucional e padronizam a interpretação dos princípios ambientais fundamentais e comandos legais que são recorrentemente negligenciados e/ou mal interpretados por outras instâncias judiciais, são orientações importantes para apoiar os processos decisórios em relação às disputas ambientais, representam o desenvolvimento e a consolidação de técnicas de interpretação mais apuradas da legislação ambiental no Tribunal Superior do país.

No entanto, analisaremos brevemente mais profundamente alguns princípios representativos que fornecem em nosso entendimento bons exemplos do alinhamento da Corte com o emergente Estado de Direito pela natureza. Princípios de acordo com Dworkin: 
São comandos de ponderação, ou seja, não estamos diante de um fato em que será atribuído diretamente uma norma jurídica, mas ponderar-se a partir do caso concreto. É um suporte do direito que deve ser observado na criação, interpretação e aplicação da norma jurídica, pois sistematizam e concebem institutos. (SOUSA, 2021. p.9)

\section{PRINCÍPIO DA PRECAUÇÃO E dA PREVENÇÃo}

O princípio da precaução e da prevenção são amplamente reconhecidos na jurisprudência brasileira, embora tribunais e juízes nem sempre cheguem a um consenso sobre sua extensão, eles estão ligados a situações de risco em virtude da dinâmica do conhecimento científico.

Em ambos os casos se adotam medidas em favor do meio ambiente, tirando o "elemento" de circulação, assim é adotada uma postura de fixação de determinados procedimentos de segurança. Importante salientar que o risco deve ser relevante, tais princípios não se baseiam no "direito do medo".

A tendência primária em âmbito global em matéria de Direito Ambiental é a prevenção e não a reparação O princípio da prevenção visa evitar que o dano possa ser produzido e por tanto ocorre adoção de medidas preventivas, mas não são aplicado em qualquer tipo de situação sendo necessário que se tenha certeza científica do impacto ambiental de determinada atividade, assim visando diminuir ou eliminar os efeitos negativos.

O princípio da precaução é considerado uma garantia contra riscos potenciais de acordo com o estado atual do conhecimento, logo, não podendo ainda ser identificado, a incerteza científica milita em favor do meio ambiente, devendo o interessado provar que as intervenções pretendidas não são perigosas ou danosas ao meio ambiente, todavia o risco deve ser grave e irreversível, pois não sendo inviabilizaria o próprio desenvolvimento econômico e científico.

Veja julgado do STJ:

PROCESSUAL CIVIL E AMBIENTAL -AÇÃO CIVIL PÚBLICA -DANO AMBIENTAL -ADIANTAMENTO DE HONORÁRIOS PERICIAIS PELO PARQUET -MATÉRIA PREJUDICADA -INVERSÃO DO ÔNUS DA PROVA -ART. $6^{\circ}$, VIII, DALEI 8.078/1990 C/C OART. 21 DALEI 7.347/1.985-PRIN- 
CÍPIO DA PRECAUÇÃO. (...) JUSTIFICA-SE AINVERSÃO DO ÔNUS DA PROVA, TRANSFERINDO PARA O EMPREENDEDOR DA ATIVIDADE POTENCIALMENTE PERIGOSA O ÔNUS DE DEMONSTRAR A SEGURANÇA DO EMPREENDIMENTO, A PARTIR DA INTERPRETAÇÃO DO ATE. 6 ${ }^{\circ}$, VIII, DA LEI 8.078/1 990 ELE C/C 21 DA LEI 7.34711 985, CONJUGADO AO PRINCÍPIO AMBIENTAL DA PRECAUÇÃO. (STJ, RESP. 972902 I RS, REI. MIN. ELIANA CALMON, DJE 14/09/2009)

Quadro 1: Precaução e Prevenção

\begin{tabular}{|l|l|}
\hline \multicolumn{1}{|c|}{ PRECAUÇÃo } & PREVENÇÃo \\
\hline Risco atrelado a incerteza científica, ocorre & Aqui o conhecimento científico tem certeza \\
algo que do ponto de vista científico pode ou & que existe ameaça aos seres humanos e \\
não ser uma ameaça ao ser humano e demais & demais bens ambientais. Assim é preciso \\
bens naturais. É preciso tomar as medidas & tomar as medidas necessárias para evitar o \\
necessárias para se evitar o dano ambiental & dano ambiental porque as consequências de \\
por não se conhecer as consequências ou & se iniciar determinado ato, prosseguir com \\
reflexos que determinado ato, ou empreen- & ele ou suprimi-lo são conhecidas de plano. O \\
dimento, ou aplicação científica causarão ao & nexo causal é cientificamente comprovado. \\
meio ambiente no espaço e/ou no tempo. & \\
\hline
\end{tabular}

Fonte: Elaborada pelos autores

\section{PRINCÍPIO DE DESENVOLVIMENTO SUSTENTÁVEL}

O princípio do desenvolvimento sustentável, por outro lado, só recentemente começou a ser invocado pelo STJ. Em geral, diz respeito à manutenção de um meio ambiente saudável. O princípio combina fatores adjacentes dentro da sociedade, pois o desenvolvimento efetivo deve-se pautar na combinação de aspectos ambientais, econômicos e sociais, desenvolvendo os diversos aspectos naturais, sociais, culturais e econômicos a ele vinculados, para as gerações presentes e futuras. Além disso, implica também respeitar os limites biofísicos da Terra, em consonância com a ideia de uma sustentabilidade forte. 
Os casos emblemáticos relacionados com a sua aplicação estão relacionados com a interpretação do artigo 54 da Lei de Crimes de Direito Ambiental, que está relacionado com o crime de poluir o meio ambiente em qualquer forma.

Os princípios de desenvolvimento sustentável e prevenção estabelecidos pelo art. 225 da Constituição Federal devem nortear a interpretação das leis ambientais, sejam elas administrativas ou criminais, uma vez que o meio ambiente é patrimônio desta geração e das que virão, bem como direito fundamental, o que deve resultar em condutas cautelosas, evitando o risco de causar danos mesmo que potenciais ao meio ambiente. (SOUSA, 2021)

\section{O PRINCÍPIO DA SOLIDARIEDADE INTERGERACIONAL}

O presente princípio visa combinar fatores adjacentes dentro da sociedade, pois o desenvolvimento efetivo deve-se pautar na combinação de aspectos ambientais, econômicos e sociais, não sendo passível de ser alcançado isoladamente sendo necessário acoplar todos esses elementos.

É delimitado pelas grandes convenções ambientais que o maior problema que impede uma ampla e efetiva tutela ambiental é a pobreza e a intergeracionalidade da tutela ambiental, tendo em vista que o desenvolvimento sustentável é pensado na conjuntura da geração atual com futuras, um grande problema, pois o modelo econômico atual busca a obtenção de riquezas ilimitadas e imediatas. (SOUSA, 2021, p. 9)

A importância desse princípio se dá em razão do pensamento de cidadania intergeracional, o efetivo exercício da cidadania é para os cidadãos de hoje e do futuro.

O desenvolvimento é inerente aos povos, razão pela qual existe indicação da ONU como direito ao meio ambiente equilibrado ser inalienável, mas o que se observa é que o crescimento econômico afeta diretamente os recursos naturais, todavia alguns desses bens utilizados são escassos e essenciais à manutenção da vida com qualidade em todas as suas formas, a utilização crescente faz com que o questionamento de até quando teremos recursos ambientais que proporcionam avanços econômicos e vida digna aos habitantes da terra. (SOUSA, 2021, p. 10) 


\section{CONCLUSÃO}

De modo geral, observamos que o direito ambiental se depara no antropoceno com grandes desafios que exigem que os juristas revisem seus próprios fundamentos. Um estado de direito emergente para a natureza exige, portanto, o esverdeamento de todos os níveis de governança e a obtenção de um equilíbrio entre os valores 'bem-estar humano' e 'natureza'.

Na esfera judicial, isso implica na necessidade de juízes mais qualificados tecnicamente que compreendam a complexidade das questões ambientais, a adoção de técnicas de interpretação adequadas, em consonância com os princípios e estratégias da hermenêutica ambiental, e a verdadeira operacionalização do marco constitucional do país, que já garante uma proteção notável ao meio ambiente.

Concluindo, o Judiciário brasileiro está percorrendo um notável caminho de aprimoramento da compreensão das questões e legislações ambientais e, com isso, o STJ desempenha um papel importante no esclarecimento de grandes controvérsias, ajudando a superar um dos principais desafios da legislação ambiental brasileira. , ou seja, sua interpretação adequada.

Suas recém-lançadas Teses de Direito Ambiental reuniram importantes decisões judiciais de base ecológica, oferecendo um instrumento de auxílio à tomada de decisões judiciais nas respectivas matérias. É certo que muito ainda deve ser feito no enfrentamento das grandes questões ambientais do Brasil, mas esses avanços recentes na jurisprudência certamente mostram que estamos caminhando para uma aplicação mais efetiva da legislação ambiental pelo Judiciário.

\section{REFERENCIAS}

BRASIL. Superior Tribunal de Justiça. Recurso Especial n 1120117 Apelação Cível n 2009/0074033-7, Rel.: Min. Eliana Calmon, Julgado em: 10/11/2009, T2 -SEGUNDA TURMA, Data de Publicação: DJe 19/11/2009). Disponível em: <http://www.stf.jus.br/> Acesso em: 01 de jan. de 2021. 
ANTUNES, Paulo de Bessa. Direito ambiental. 16. ed. São Paulo: Atlas S.A, 2014.

BENJAMIN, Antonio Herman de Vasconcellos e. Hermenêutica do Novo Código Florestal. Revista de Direito Ambiental, [ SI ], p. 1-9, 2014.

BUGGE, Hans Christian. Doze desafios fundamentais em direito ambiental: uma introdução ao conceito de Estado de Direito para a natureza. In : VOIGT, Christina. Estado de direito para a natureza: novas dimensões e ideias no direito ambiental. Cambridge: Cambridge University Press, 2013. p. 3-26.

de Sousa, L. M. R. (2021). Políticas de conservação e critérios ambientais: princípios, conceitos e protocolos. Conexão ComCiência, 1(2). Recuperado de https:// revistas.uece.br/index.php/conexaocomciencia/article/view/4824

MORATO LEITE, José Rubens e Germana Belchior. Estado de direito ambiental: uma análise da recente jurisprudência ambiental do STJ sob o enfoque da hermenêutica jurídica. Revista de Direito Ambiental, [ SI ], v. 56, p. 55-92, 2009 


\section{SOBRE OS ORGANIZADORES}

\section{LUGAS MELO RODRIGUES DE SOUSA}

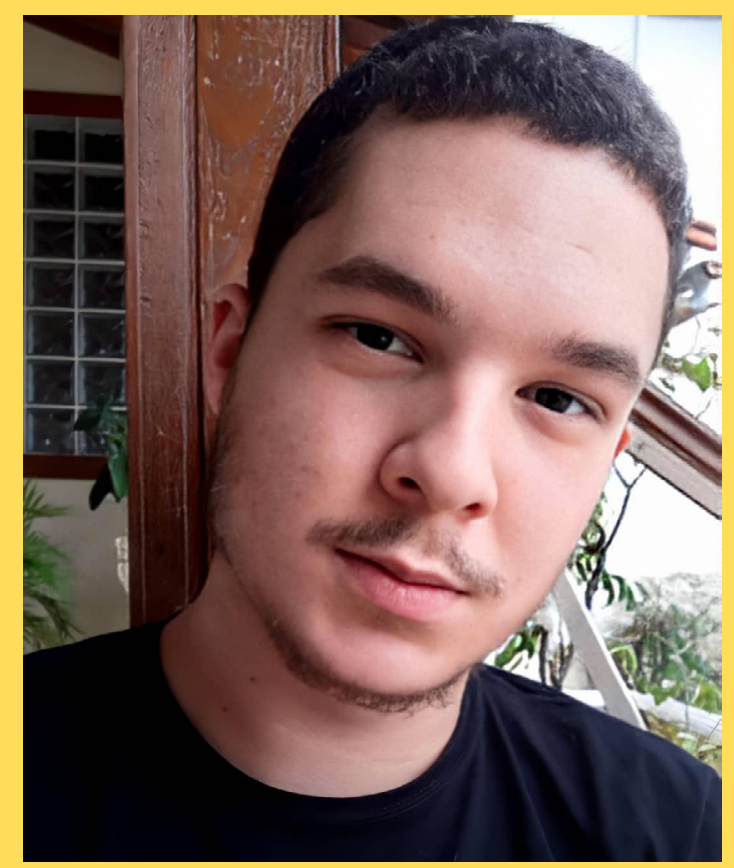

Possui graduação em Direito pela Escola Superior Dom Helder Câmara (2020). Tem experiência com ênfase em Direito, atuando principalmente nos seguintes temas: Direito do Trabalho e Processo do Trabalho (PUC-MINAS), Compilance Trabalhista (LEGALE), Direitos Humanos (CENES) e Direito Constitucional (LEGALE).

https://orcid.org/0000-0002-9718-8075

http://lattes.cnpq.br/6359239458587893 


\section{THIESER FARIAS}

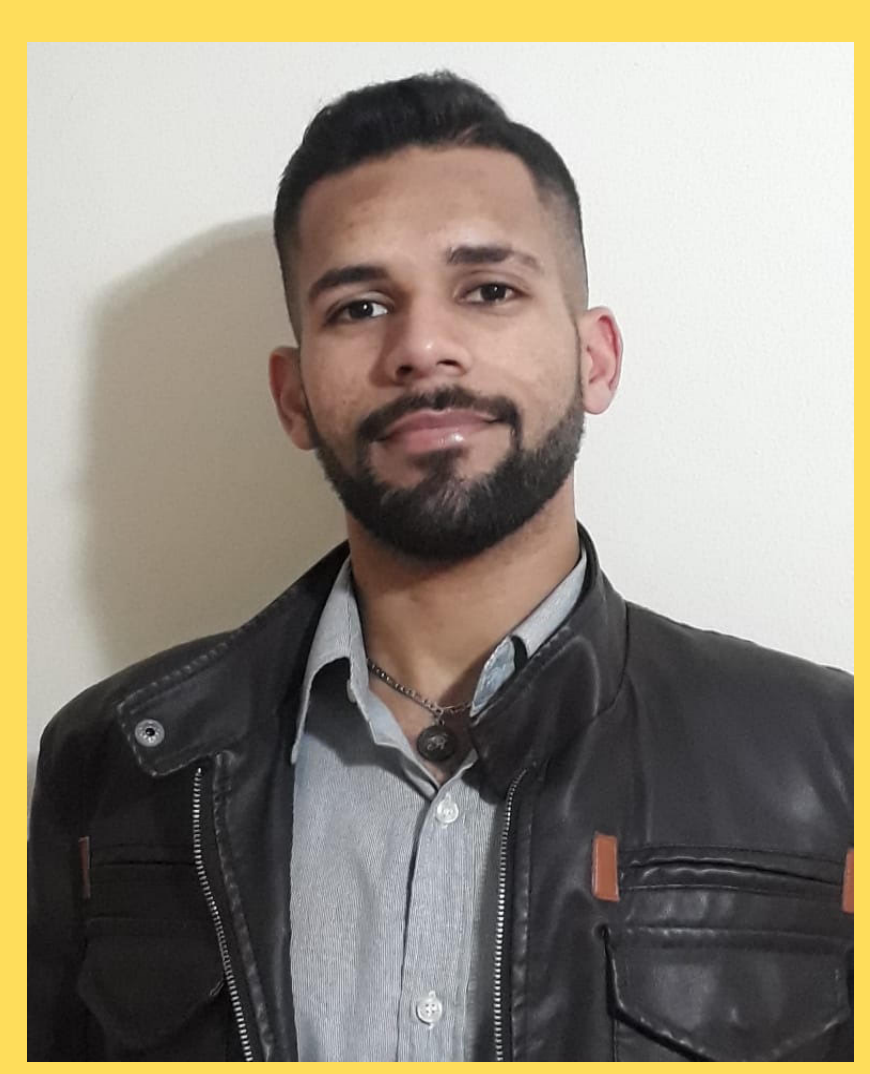

Mestrando e Graduado em Direito com Láurea Acadêmica pela Universidade Federal de Santa Maria. Aprovado no XXXII Exame Unificado da Ordem dos Advogados do Brasil. Pós- graduando em Direito Constitucional Aplicado pela Faculdade Legale. Membro do Grupo de Estudos e Pesquisas em Democracia e Constituição - GPDECON/UFSM.

E-mail: Thieserfarias94@yahoo.com.br

Currículo Lattes: http://lattes.cnpq.br/4540009812337374 


\section{SOBRE AS AUTORAS E OS AUTORES}

\section{Arthur Posser Tonetto}

Oficial do Exército Brasileiro. Mestrando em Direito pela Universidade Federal de Santa Maria. Pós-graduando em Direito Público pela Pontifícia Universidade Católica de Minas Gerais e em Direito Militar pela Verbo Jurídico; Graduado em Direito pela Faculdade de Direito de Santa Maria - FADISMA. E-mail: arthurtonetto@hotmail.com.

\section{Alexandre Jacob}

Bacharel em Direito. Mestre em Ciências das Religiões. Professor universitário. E-mail: alexandre.jacob10@gmail.com

\section{Isabela Soares de Souza}

Bacharel em Direito. Advogada. E-mail: isasoares.s@outlook.com

\section{Lucas Melo Rodrigues de Sousa}

Pós graduando em Direitos Humanos pela FOCUS bem como em Direito do Trabalho e Previdenciário pela Pontifícia Universidade Católica de Minas Gerais. Bacharel em Direito pela Escola Superior Dom Helder Câmara.

E-mail: lucasrmelo@yahoo.com

\section{Nina Trícia Disconzi Rodrigues Pigatto}

Doutora em Direito pela Universidade de São Paulo. Professora Adjunta do Departamento de Direito da Universidade Federal de Santa Maria (Graduação e Mestrado). Coordenadora do Grupo de Estudos e Pesquisas em Democracia e Constituição (GPDECON) e Grupo de Pesquisa em Direitos dos Animais (GPDA) da UFSM. E-mail: nina.rodrigues@ufsm.br.

\section{Raphael Teixeira do Vale}

Bacharel em Direito pela Escola Superior Dom Helder Câmara

\section{Thieser da Silva Farias}

Mestrando e Graduado em Direito pela Universidade Federal de Santa Maria. Pós- graduando em Direito Constitucional Aplicado pela Faculdade Legale. Membro do Grupo de Estudos e Pesquisas em Democracia e Constituição GPDECON/UFSM. E-mail: Thieserfarias94@yahoo.com.br 

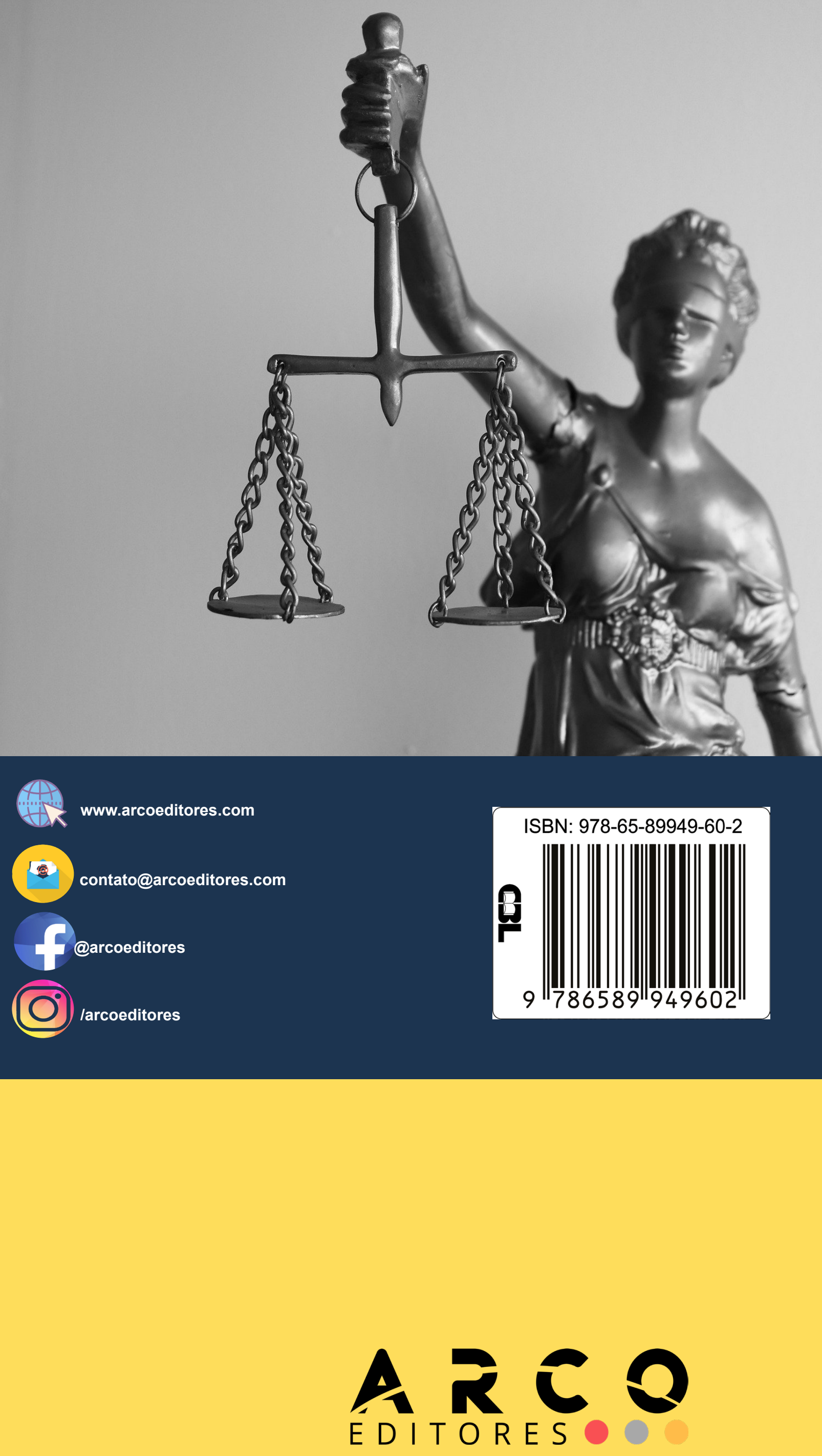